\title{
Article \\ Catalytic Effect of 1,4-Dioxane on the Kinetics of the Oxidation of Iodide by Dicyanobis(bipyridine)iron(III) in Water
}

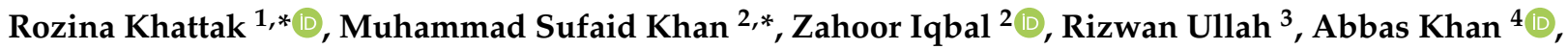 \\ Shazia Summer ${ }^{5}$, Hamsa Noreen ${ }^{6}$, Muhammad Zahoor ${ }^{7}$ (D), Salah M. El-Bahy ${ }^{8}$ and Gaber El-Saber Batiha ${ }^{9}$
}

\section{check for}

updates

Citation: Khattak, R.; Khan, M.S.; Iqbal, Z.; Ullah, R.; Khan, A.; Summer, S.; Noreen, H.; Zahoor, M.; El-Bahy, S.M.; Batiha, G.E.-S. Catalytic Effect of 1,4-Dioxane on the Kinetics of the Oxidation of Iodide by Dicyanobis(bipyridine)iron(III) in Water. Catalysts 2021, 11, 840. https://doi.org/10.3390/catal11070840

Academic Editors: Tannistha Roy Barman and Manas Sutradhar

Received: 30 May 2021

Accepted: 6 July 2021

Published: 11 July 2021

Publisher's Note: MDPI stays neutral with regard to jurisdictional claims in published maps and institutional affiliations.

Copyright: (c) 2021 by the authors. Licensee MDPI, Basel, Switzerland. This article is an open access article distributed under the terms and conditions of the Creative Commons Attribution (CC BY) license (https:// creativecommons.org/licenses/by/ $4.0 /)$
1 Department of Chemistry, Shaheed Benazir Bhutto Women University, Peshawar 25000, Pakistan 2 Department of Chemistry, University of Malakand, Chakdara 18800, Pakistan; arhamiqbal2017@gmail.com 3 National Center of Excellence in Physical Chemistry, University of Peshawar, Peshawar 25120, Pakistan; drrizwan@uop.edu.pk

4 Department of Chemistry, Abdul Wali Khan University Mardan, Mardan 23200, Pakistan; abbas80@awkum.edu.pk

5 Department of Chemistry, Jinnah University for Women, Karachi 74600, Pakistan; shaziasamar@hotmail.com 6 Institute of Chemical Sciences, University of Peshawar, Peshawar 25120, Pakistan; hamsaics@yahoo.com

7 Department of Biochemistry, University of Malakand, Chakdara 18800, Pakistan; zahoor@uom.edu.pk

8 Department of Chemistry, Turabah University College, Taif University, P.O. Box 11099, Taif 21944, Saudi Arabia; s.elbahy@tu.edu.sa

9 Department of Pharmacology and Therapeutics, Faculty of Veterinary Medicine, Damanhour University, Damanhour 22511, Egypt; gaberbatiha@gmail.com

* Correspondence: rznkhattak@yahoo.com or rznkhattak@sbbwu.edu.pk (R.K.); sufaidkhan1984@uom.edu.pk (M.S.K.)

Abstract: Dye-sensitized solar cells (DSSCs) are a technically and financially viable alternative to today's photovoltaic systems using p-n junctions. The two functions are isolated here, which are unlike traditional systems where the semiconductor is thought to perform both light absorption and charge carrier transport. This article discusses the potential use of dicyanobis(bipyridine)iron(III) to oxidize iodide as a sensitizer in DSSCs. However, it is critical to understand the kinetics of this essential process in order to understand the mechanism of electron transport. The oxidation of iodide by dicyanobis(bipyridine)iron(III) in three reaction media was studied: water, $10 \% v / v$ 1,4-dioxanewater, and $20 \% v / v$ 1,4-dioxane-water. The reaction was carried out in a regular laboratory setting, with no special sensitive conditions or the use of expensive materials, making it a cost-effective and practical method. Dicyanobis(bipyridine)iron(III) oxidized iodide in selected media at $0.06 \mathrm{M}$ ionic strength and constant temperature. The reaction was subjected to a spectrophotometric analysis. The data were acquired by measuring the rise in visible absorbance as a function of time after the formation of dicyanobis(bipyridine)iron(II). The reaction proceeded with an overall fractional (0.5), first order, and third order in water, $10 \%$ media, and $20 \%$ media, respectively. The presence of dicyanobis(bipyridine)iron(III) in either of the reaction media had no effect on the rate. The effect of protons $\left(\mathrm{H}^{+}\right)$on the rate constant indicated resistance in water and catalysis in dioxane-water media containing $10-20 \%$ dioxane. When the ionic strength was raised, there was no change in the rate constant in water, but there was a deceleration in both binary solvent media. In an aqueous medium, the thermodynamic parameters of activation were computed as $\mathrm{E}_{\mathrm{a}} 46.23 \mathrm{~kJ} \mathrm{~mol}^{-1}, 24.62 \mathrm{M} \mathrm{s}^{-1}, \Delta \mathrm{H}^{\#}$ $43.76 \mathrm{~kJ} \mathrm{~mol}^{-1}, \Delta \mathrm{S}^{\#}-226.5 \mathrm{~J} \mathrm{~mol}^{-1} \mathrm{~K}^{-1}$, and $\Delta \mathrm{G}^{\#} 111.26 \mathrm{~kJ} \mathrm{~mol}^{-1}\left(25^{\circ} \mathrm{C}\right)$. By increasing the rate of the reaction to its maximum, this study discovered the binary solvent media with the highest catalytic efficiency, i.e., $20 \% v / v$ 1,4-dioxane-water, which may increase the efficiency of DSSCs without using any expensive material or unusual experimental conditions.

Keywords: photosensitive; sensitizer; 1,4-dioxane-water; dicyanobis(bipyridine)iron(III); oxidation; iodide 


\section{Introduction}

Energy researchers are focusing their efforts on energy harvesting from a range of sources since the ever-increasing human population needs the usage of energy in numerous ways. Fossil fuels and other nonrenewable energy sources are dwindling and will not be replenished in our lifetimes. Carbon-based fossil fuels such as coal, petroleum, and natural gas are nonrenewable energy sources, and they release greenhouse gases (such as carbon dioxide) that cause global warming, posing a severe threat to the earth and humanity. As a result, scientists' primary attention is on renewable energy-based energy conversion technologies. Solar, wind, hydroelectric, biomass, and geothermal energy are some of the renewable energy resources that our planet has to offer. Solar energy is a significant source of renewable energy that is available $24 \mathrm{~h}$ a day, 365 days a year, and it is virtually unlimited in nature. Sunlight-derived radiation can produce heat and light as well as drive photochemical reactions and generate electricity in the case of solar energy. As electricity becomes humanity's first and the most basic necessity, this amazing energy source may be exploited to convert solar energy to electrical energy, utilizing solar cell technology. Unfortunately, even though solar energy is free, the high costs of conversion and storage limit the technology's accessibility. As a result of their relatively low cost, easy preparation technique, low toxicity, and ease of processing, dye-sensitized solar cells (DSSCs) have been the subject of extensive research [1-10]. Despite this, due to their high cost, scarcity, and lack of long-term stability, the present DSSC materials have a lot of room for replacement. Existing DSSCs have an efficiency of up to $12 \%$ when employing $\mathrm{Ru}(\mathrm{II})$ dyes and improving material and structural features, but this is still less than the $20-30 \%$ efficiency of solar cells from the first and second generations, such as thin-film solar cells and Si-based solar cells $[2,3,9]$.

The emerging advances and basic concepts for DSSCs must be understood in order to achieve higher solar-to-electricity performance and increase long-term operating stability [4]. DSSCs are built on a semiconductor that is engineered with titanium dioxide $\left(\mathrm{TiO}_{2}\right)$ nanoparticles coated with a light-sensitive dye. On the surface of $\mathrm{TiO}_{2}$, a metal complex or a dye molecule absorbs the incident photon and acts as a photosensitizer. The excited electrons are subsequently pushed into the $\mathrm{TiO}_{2}$ electrode (conduction band), causing the photosensitizer to be oxidized. The injected electrons in $\mathrm{TiO}_{2}{ }^{\prime} \mathrm{s}$ conduction band diffuse between $\mathrm{TiO}_{2}$ nanoparticles, eventually reaching the counter electrode via the circuit. The ground state is regenerated when the oxidized photosensitizer accepts electrons from the mediator or the electrolyte. DSSCs break the two functionalities offered by silicon in a traditional cell architecture. This energy can be stored and used to power electrical device loads. They can generate electricity in low-light environments, such as those found in homes [3]. The cell has colors and transparency due to the structural nature and various color dyes. As a result, DSSCs are applicable to architecture, interior design, mobile devices, and portable power systems [1]. These solar cells outperform their counterparts in a variety of applications, including low-density applications and portable devices $[1,8,11,12]$.

The three subsystems that make the DSSC work are the photoanode with an adsorbed sensitizer such as $\mathrm{TiO}_{2}$ with dye, the electrolyte that functions as an electron mediator, and the catalytic counter electrode. These three subsystems must be improved in order for the DSSC to become more efficient. A cell consisting of a $\mathrm{TiO}_{2}$ electrode, sensitizer/dye, a liquid electrolyte ( $\mathrm{LiI} / 0.5 \mathrm{M}, \mathrm{I}_{2} / 0.05 \mathrm{M}$, and $0.2 \mathrm{M} \mathrm{TBP}$ in acetonitrile or 3-methoxypropionitrile), a platinized counter electrode, and polymer-based sealing has been used to achieve a reasonable solar energy conversion efficiency [13-15]. Different advancements were made in the scientific community, and various materials, including photoanode nanomaterials, were synthesized and employed to improve the efficiency of DSSCs. Silver nanoparticles infused titanium dioxide film [16], graphene-based and $\mathrm{TiO}_{2}-\mathrm{CeO}_{2}$ photoanodes [17,18], $\mathrm{ZnO} / \mathrm{TiO}_{2}$ composite film [19], and $\mathrm{Li}-\mathrm{ZnO}$ nanoparticles at $\mathrm{SnO}_{2}$ nanocomposite photoanode [20] are some of the recent advances in this field. Meanwhile, there has been a lot of effort put into improving the efficiency of the counter electrode (CE) by using new material(s), nanomaterial(s), and nanocomposite(s) as the counter electrode, or by 
using external catalysts for the counter electrode. Counter electrodes made of carbon materials [21], NiO with PEDOT:PSS [22], PdNiCo and PdNiCo-rGO [23], $\mathrm{MoS}_{2} / \mathrm{PEDOT}$ composite [24], graphite nanoball, graphite nanosheet, and graphite nanofiber as catalytic films on CE [25], platinum with multiwall carbon nanotubes (MWCNT) as a catalytic layer for the reduction of $\mathrm{I}_{3}{ }^{-}[26]$, and cobalt selenide/graphene composite as the electrocatalyst for CE with a cobalt-based electrolyte [27] were studied.

The production of new dyes and electron mediators, as well as a better understanding of their interactions and the interfacial electron transfer kinetics is critical for future advancement in this field and is currently the focus of the DSSCs community's scientific efforts [6-8,10,28-36]. In terms of kinetics, efficient cell performance is attained when electron transfer events happen quickly. When choosing materials for DSSCs, a balance between thermodynamics and kinetics must be achieved. Natural dyes [37], zinc porphyrin dye, and Co(II/III)tris(bipyridine)-based redox electrolyte [38], co-sensitization of two metalfree organic dyes and Co(II/III)tris(phenanthroline)-based redox electrolyte [39], Fe(II)bis(terpyridine) and its cyclometalated analogues [40], $\mathrm{Ru}(\mathrm{NCS})_{2} \mathrm{LL}^{\prime}$, in which L refers to $4,4^{\prime}$-dinonyl-2,2' -bipyridine and $\mathrm{L}^{\prime}$ stands for 4,4'-di(m-X-benzoic acid)-2,2' -bipyridine $(\mathrm{X}=\mathrm{H}(\mathrm{RC}-73), \mathrm{F}(\mathrm{RC}-76))[41]$, and $\left[\mathrm{Cd}_{3}(\mathrm{IBA})_{3}(\mathrm{Cl})_{2}(\mathrm{HCOO})\left(\mathrm{H}_{2} \mathrm{O}\right)\right] \mathrm{n}$ as co-sensitizers in N719 sensitized solar cells [42] are some improvements.

One of the most important components in dye-sensitized solar cell devices is the redox mediator, which is also known as a redox shuttle or electrolyte and the solvent used for electrolyte i.e., electrolyte solvent. The efficiency of DSSCs has been determined using a variety of electrolyte solvents, and it has been found that the solvent or medium has a significant impact on the efficiency. A non-nitrile solvent, acetylacetone [43], mixed solvent of tetrahydrofuran (THF) and acetonitrile [44], water and mixture of acetonitrile and ethylene glycol [45], ionic liquids [46], gel-type electrolyte with ionic liquid and liquidtype electrolyte [47], $30 \mathrm{vol} \%$ NMP with $70 \mathrm{vol} \%$ GBL and $30 \mathrm{vol} \%$ NMP with $70 \mathrm{vol} \% \mathrm{GBL}$ + 0.4 M pyridine [48], sugar-based natural deep eutectic solvents (NADESs) and NADES as a fully natural and bio-renewable dye-sensitized solar cell medium [49] and 1:1 wt\% ethylene carbonate (EC) and propylene carbonate (PC) containing iodide/triiodide redox electrolyte [50] have been used.

Despite the fact that the $\mathrm{I}^{-} / \mathrm{I}_{3}-$ redox couple has dominated in recent decades, the volatile nature of the material, complementary absorption with a sensitizer, and the lack of open-circuit potential limit module manufacturing. Metal complexes with changeable oxidation states are viable alternate possibilities as redox shuttles because of the variation in their redox potentials with varied ligands to accommodate diverse sensitizers. In DSSC, polypyridyl liganded Co(III)/(II) redox couples have been widely used, with a system efficiency of $14 \%$ [35,51]. Consequently, the transition metal complexes of Fe(III)/(II) with polypyridyl ligands may have the potential to increase the performance of the DSSC if used as a sensitizer to oxidize iodide [13,36,52-65].

Low cost and volatility, non-flammability, and increased environmental compatibility could all be achieved with DSSCs made with water-based electrolytes. If the original goal of DSSCs was to build an artificial photosynthetic system that could convert solar light into power, the inclusion of water as a crucial component could be a huge step ahead in terms of market adoption [66]. In this study, dicyanobis(bipyridine)iron(III) oxidizes iodide in water and dioxane-water media. The kinetics of the reaction was studied to surface the catalytic efficacy of the binary solvent media. Dioxane is entirely miscible with water and is resistant to oxidation by oxidants present throughout the reaction, such as the reactant Fe(III) complex and the products iodine or triiodide. Dicyanobis(bipyridine)iron(III) is an excellent option for use as a sensitizer in DSSCs because of its photosensitive nature. This is a cost-effective and environmentally friendly reaction because it uses readily available reagents such as potassium iodide, potassium nitrate, and 1,4-dioxane, as well as a lowcost transition metal complex of non-harmful Fe(III)/(II) with potential for stability and efficiency improvement of DSSC without the use of costly materials. 


\section{Results and Discussion}

\subsection{Kinetic Parameters of Uncatalyzed Reaction in Water}

\subsubsection{Overall Order of Reaction and the Overall Rate Constant of Uncatalyzed Reaction}

The oxidation of iodide by dicyanobis(bipyridine)iron(III) was studied in water. The kinetic parameters such as order of reaction with respect to the reactants and the overall rate constant were determined at $0.06 \mathrm{M}$ ionic strength. The ionic strength was maintained by potassium nitrate $\left(\mathrm{KNO}_{3}\right)$. The concentration of dicyanobis(bipyridine)iron(III) nitrate was constant at $0.08 \mathrm{mM}$ and that of potassium iodide varied between 0.08 and $4 \mathrm{mM}$ at $293 \pm 0.5 \mathrm{~K}$. Linear rate equations of the integration method of various orders as derived and published earlier [36] were implemented on the acquired data to identify the order of reaction with respect to dicyanobis(bipyridine)iron(III). As a result of the most acceptable linear fit R-squared value above other orders, the reaction was observed to undergo the zero order with respect to the concentration of the oxidant; dicyanobis(bipyridine)iron(III) (Equation (1), Figure 1).

$$
[\mathrm{A}]_{\mathrm{t}}=[\mathrm{A}]_{0}+\varepsilon \cdot \mathrm{b} \cdot k_{\mathrm{obs}} \cdot \mathrm{t}
$$

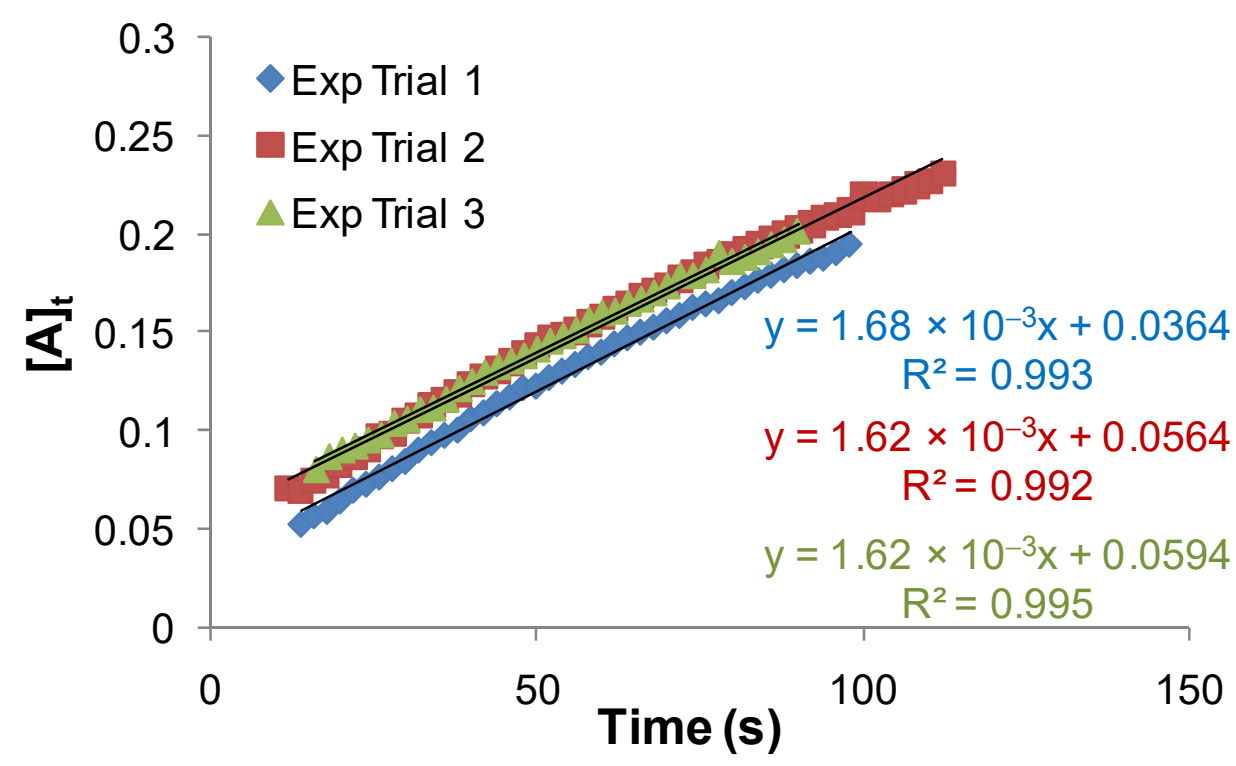

Figure 1. Linear rate equation of integration method for zero-order reaction at $3.2 \mathrm{mM}$ iodide.

The terms $\mathrm{A}, \epsilon, \mathrm{b}, k_{\mathrm{obs}}$, and $\mathrm{t}$ carry usual meanings such as absorbance at time point " $\mathrm{t}$ " and " 0 ", molar absorptivity, pathlength of cuvette $(1 \mathrm{~cm})$, observed zero-order rate constant, and time in seconds. Here, " $\epsilon$ " corresponds to the value of the molar absorptivity of the product i.e., dicyanobis(bipyridine)iron(II) that was used to monitor the increase in absorbance as a course of time to interpret the kinetics of the reaction. We observed the absorbance at $\geq$ zero time scale, which may be because of the formation of the transition state complex. In the $1 \mathrm{~s}$ time scale, the absorbance climbed and then fell quickly, and then, it progressively increased with respect to time until the reaction was completed (Figure 2a,b). The slope of the plot with dimension $\left(\mathrm{s}^{-1}\right)$ is $\epsilon \cdot \mathrm{b}\left(\mathrm{M}^{-1} \mathrm{~cm}^{-1} \mathrm{~cm}\right)$ times bigger than $k_{\mathrm{obs}}\left(\mathrm{M} \mathrm{s}^{-1}\right)$, with $\epsilon \cdot \mathrm{b}$ having no significant influence on $k_{\mathrm{obs}}$ other than the addition of a constant value. Rather than generating a distinct value of $k_{\text {obs }}$ by first computing the concentration of dicyanobis(bipyridine)iron(III) and then plotting it against time, we used the entire figure of $\epsilon \cdot \mathrm{b} \cdot k_{\mathrm{obs}}\left(\mathrm{s}^{-1}\right)$ by drawing a linear plot between absorbance at time points $t$ versus time scale. 


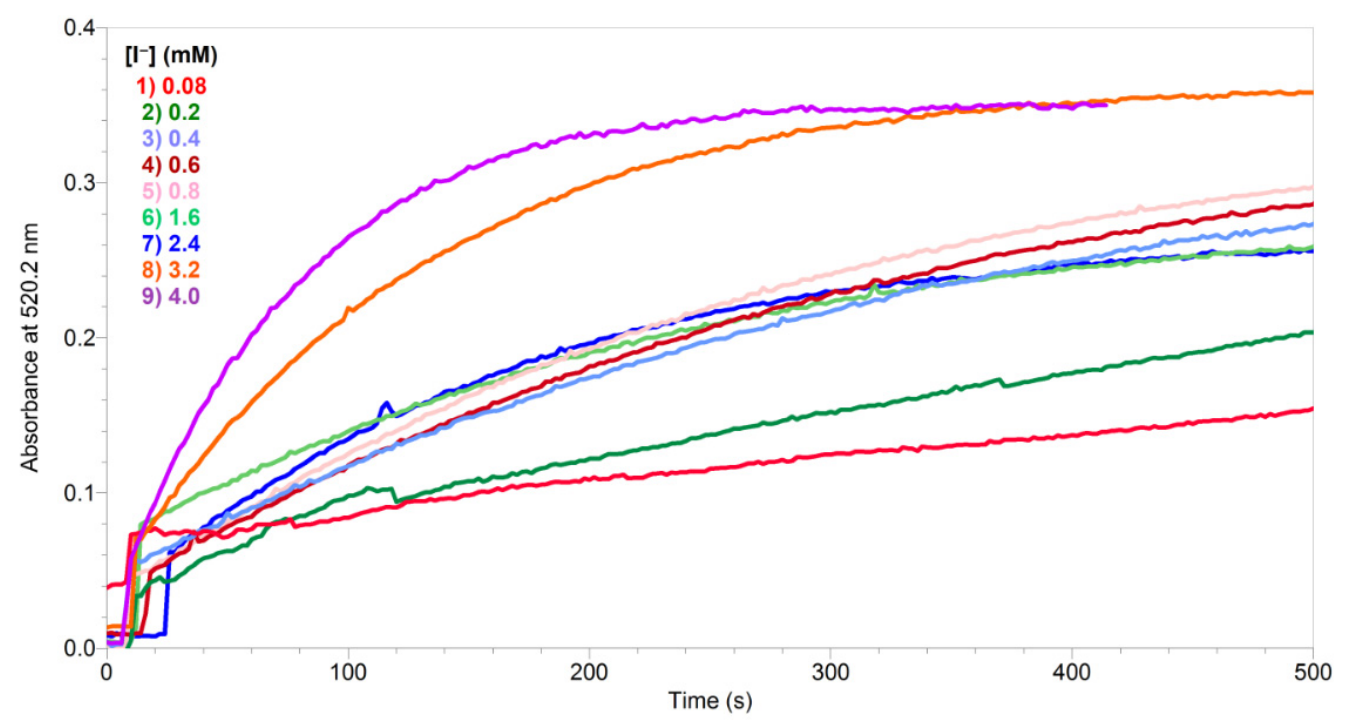

(a)

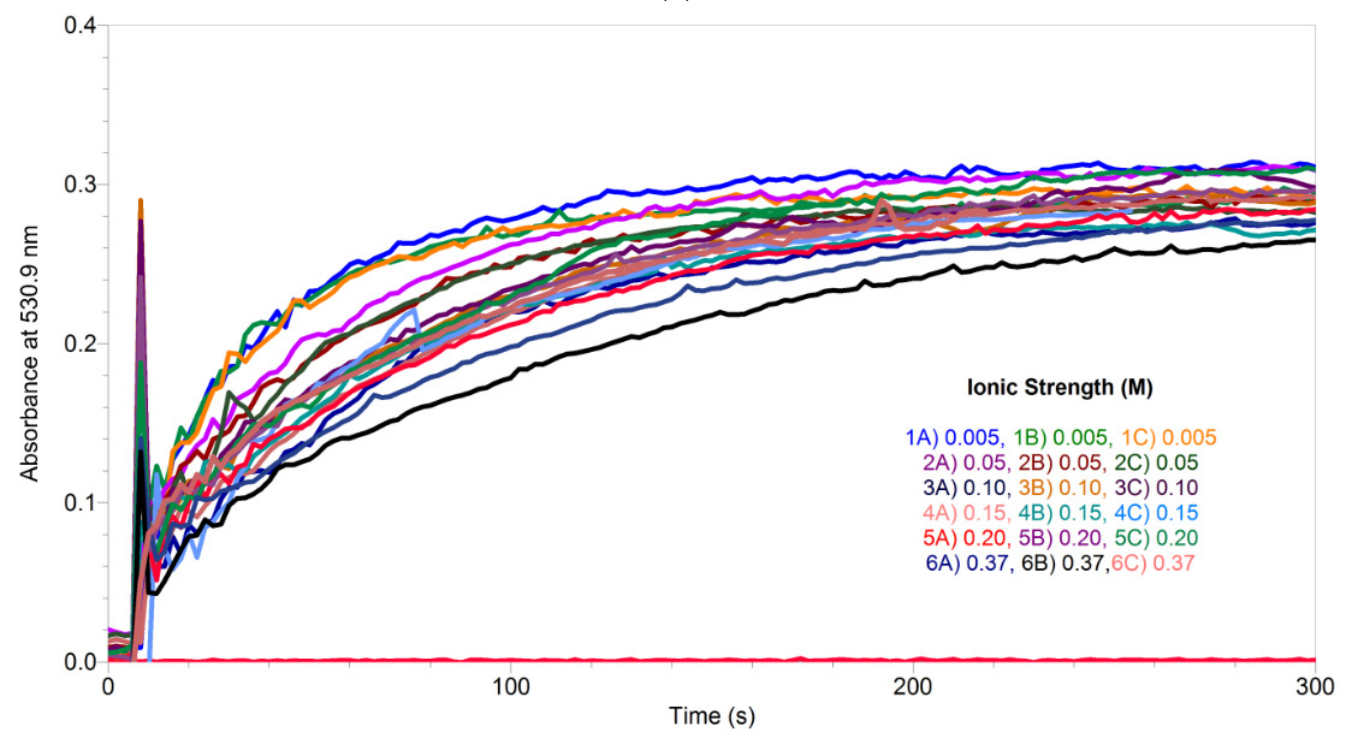

(b)

Figure 2. (a) Representative time course graphs at varying concentration of iodide in water. (b) Representative time course graphs at varying ionic strength in $10 \%(v / v)$ 1,4-dioxane-water.

The order of reaction with respect to the reductant, i.e., iodide was identified by determining the value of the slope $\epsilon \cdot \mathrm{b} \cdot k_{\mathrm{obs}}$ at a fixed $0.08 \mathrm{mM}$ oxidant and varying the concentration of iodide ion within the range between 1 and 50 times over the oxidant. The plot between the concentration of iodide ion on the $\mathrm{x}$-coordinate and $\epsilon \cdot \mathrm{b} \cdot \boldsymbol{k}_{\mathrm{obs}}$ on the y-coordinate yields an increasing curvature that indicates that the reaction does not follow zero and first order with respect to the reductant (Figure 3a). If it would have been zero order with respect to the iodide, then all the values of $\epsilon \cdot \mathrm{b} \cdot k_{\mathrm{obs}}$ should have been constant at different concentration of iodide. Similarly, if the order of reaction is supposed to be first, then a linear fit with an acceptable $\mathrm{R}^{2}$ value should have been obtained, passing through the origin of the plot. We did not observe any such result (Figure 3a). When we implemented fractional (0.5) and second-order models, we obtained curves passing through the origin, respectively (blue curves in Figure $3 b, c)$. The reaction was fractional (0.5) order in iodide (red linear fit, Figure 3b) between 1 and 30 times its concentration ratio over the oxidant i.e., dicyanobis(bipyridine)iron(III), while from 30 to 50 times its concentration ratio over the oxidant, the reaction underwent second order with respect to the iodide (red linear fit, Figure 3c). In both cases, the linear fit passes 
through the origin and yields a very promising value of $\mathrm{R}^{2}$, which confirms that the reaction follows complex kinetics corresponding to the excess concentration of iodide over dicyanobis(bipyridine)iron(III). Consequently, the oxidation of iodide follows an overall fractional (0.5) order in water within the concentration range from 0.08 to $2.4 \mathrm{mM}$ of iodide at constant $0.08 \mathrm{mM}$ of dicyanobis(bipyridine)iron(III) that oxidized iodide. Meanwhile, the redox reaction follows an overall second order at 30-50 times excess concentration of iodide over a fixed $0.08 \mathrm{mM}$ concentration of dicyanobis(bipyridine)iron(III). In both phases of the reaction, the rate of the oxidation of iodide was observed independent of the concentration of dicyanobis(bipyridine)iron(III) in water that yielded zero order in oxidant. The overall fractional $(0.5)$ order rate constant $(\epsilon \cdot \mathrm{b} \cdot k)$ and overall second-order rate constant $\left(\epsilon \cdot \mathrm{b} \cdot k^{\prime}\right)$ were determined from the slope of the plots as $2.11 \times 10^{-2} \mathrm{M}^{-0.5} \mathrm{~s}^{-1}$ and $1.68 \times 10^{2} \mathrm{M}^{-2} \mathrm{~s}^{-1}$, respectively. The conventional dimensions of the fractional (0.5) and second-order rate constants are $\mathrm{M}^{0.5} \mathrm{~s}^{-1}$ and $\mathrm{M}^{-1} \mathrm{~s}^{-1}$, respectively. However, in our case, the dimensions are different because of the multiplication of $\epsilon \cdot \mathrm{b}$ to the fractional and second-order rate constants according the resulting Equations (19) and (20) obtained by Equations (2)-(18). Conventionally, we assume the rate of any reaction at the beginning of the study considering the reactants and products of the reaction as follows.

$$
\begin{gathered}
2\left[\mathrm{Fe}^{\mathrm{III}}(\mathrm{bpy})_{2}(\mathrm{CN})_{2}\right]^{+}+2 \mathrm{I}^{-} \rightarrow 2\left[\mathrm{Fe}^{\mathrm{II}}(\mathrm{bpy})_{2}(\mathrm{CN})_{2}\right]+\mathrm{I}_{2} \\
\text { Rate }=k\left[\mathrm{Fe}^{\mathrm{III}}(\mathrm{bpy})_{2}(\mathrm{CN})_{2}^{+}\right]\left[\mathrm{I}^{-}\right] \\
\text {At pseudo }- \text { first order condition such as }\left[\mathrm{I}^{-}\right]>>>\left[\mathrm{Fe}^{\mathrm{III}}(\mathrm{bpy})_{2}(\mathrm{CN})_{2}^{+}\right] \\
\text {Rate }=k_{\mathrm{obs}}\left[\mathrm{Fe}^{\mathrm{III}}(\mathrm{bpy})_{2}(\mathrm{CN})_{2}^{+}\right]
\end{gathered}
$$

The rate in Equation (4) can also be written in terms of the formation of dicyanobis (bipyridine)iron(II). There is a 1:1 ratio of electron acceptance between the redox couple as follows.

$$
\left[\mathrm{Fe}^{\mathrm{III}}(\mathrm{bpy})_{2}(\mathrm{CN})_{2}\right]^{+}+\overline{\mathrm{e}} \leftrightarrow\left[\mathrm{Fe}^{\mathrm{II}}(\mathrm{bpy})_{2}(\mathrm{CN})_{2}\right]
$$

The molar concentration of the reduction or consumption of dicyanobis(bipyridine)iron (III) yields the same molar concentration of the product i.e., dicyanobis(bipyridine)iron(II). Consequently, the concentration ratio between dicyanobis(bipyridine)iron(III)/(II) is equal. However, Equation (4) can be rearranged into Equation (7).

$$
\begin{gathered}
\frac{\mathrm{d}\left[\mathrm{Fe}^{\mathrm{II}}(\mathrm{bpy})_{2}(\mathrm{CN})_{2}\right]}{\mathrm{dt}}=k_{\mathrm{obs}}\left[\mathrm{Fe}^{\mathrm{III}}(\mathrm{bpy})_{2}(\mathrm{CN})_{2}{ }^{+}\right] \\
\frac{\mathrm{d}\left[\mathrm{Fe}^{\mathrm{II}}(\mathrm{bpy})_{2}(\mathrm{CN})_{2}\right]}{\left[\mathrm{Fe}^{\mathrm{III}}(\mathrm{bpy})_{2}(\mathrm{CN})_{2}{ }^{+}\right]}=k_{\mathrm{obs}} \mathrm{dt}
\end{gathered}
$$

If absorbance is monitored as a time course graph rather than concentration, Equations (8)-(10) are produced as the consequent equations after integration, solution, and application of the Beer-Lambert law. If the change in concentration is observed over time, Equation (8) shows the rate of reaction in terms of molar concentration $\left(\left[\mathrm{Fe}^{\mathrm{II}}(\mathrm{bpy})_{2}(\mathrm{CN})_{2}\right]\right)$, and Equations (9) and (10) show the rate in terms of rise in absorbance (A) over time.

$$
\begin{gathered}
\ln \frac{\left[\mathrm{Fe}^{\mathrm{II}}(\mathrm{bpy})_{2}(\mathrm{CN})_{2}\right]_{\mathrm{t}}}{\left[\mathrm{Fe}^{\mathrm{II}}(\mathrm{bpy})_{2}(\mathrm{CN})_{2}\right]_{0}}=k_{\mathrm{obs}} \cdot \mathrm{t} \\
\ln \frac{[\mathrm{A}]_{\mathrm{t}}}{[\mathrm{A}]_{0}}=k_{\mathrm{obs}} \cdot \mathrm{t}
\end{gathered}
$$




$$
\ln [\mathrm{A}]_{\mathrm{t}}=\ln [\mathrm{A}]_{0}+k_{\mathrm{obs}} \cdot \mathrm{t}
$$

Equations (8)-(10) are the typical integrated rate equations of linear regression for first-order reaction under pseudo-first-order condition. These equations help to identify the order of reaction with respect to the reactant that is maintained at low concentration where $k_{\text {obs }}$ is the observed pseudo-first-order rate constant with dimension $\mathrm{s}^{-1}$. Then, the value of $k_{\text {obs }}$ is used to identify the order of reaction with respect to the other reactant that was maintained at excess concentration during the implementation of the pseudo-first-order condition. For a typical first-order reaction, Equation (11) is used in such circumstances.

$$
k_{\mathrm{obs}}=k\left[\mathrm{I}^{-}\right]
$$

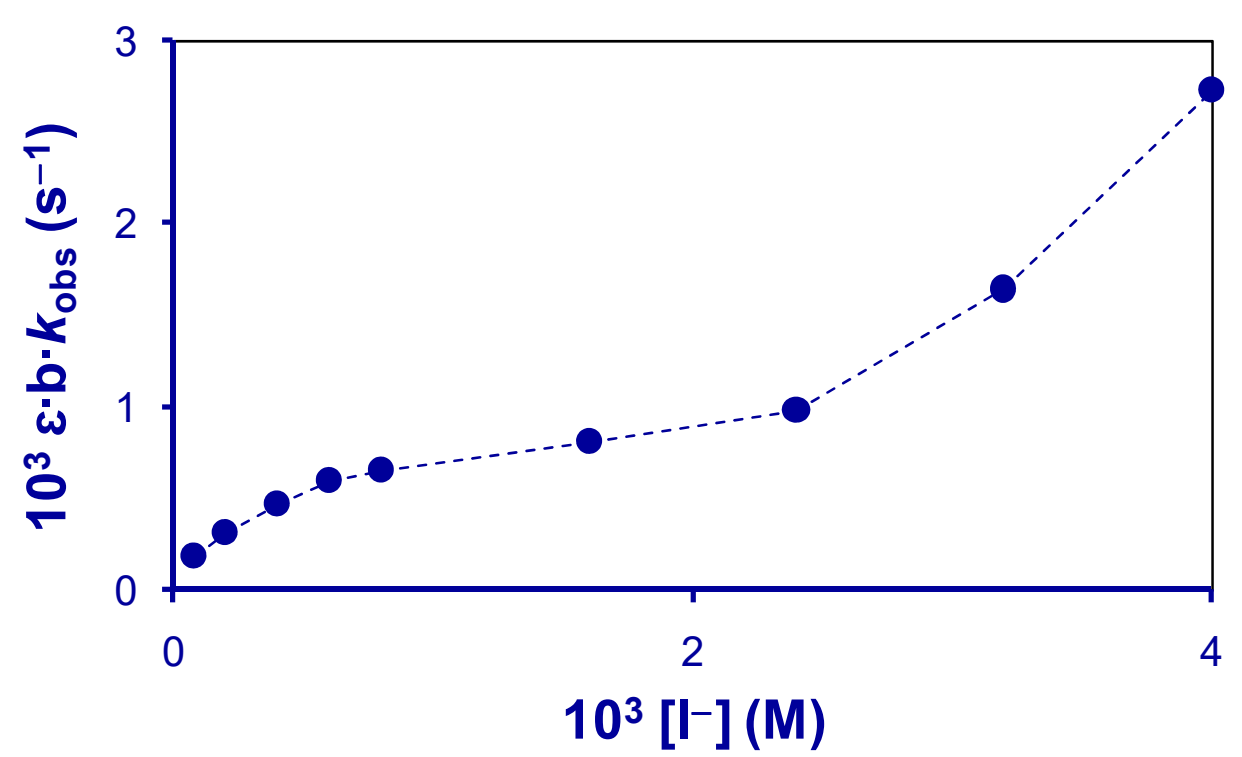

(a)

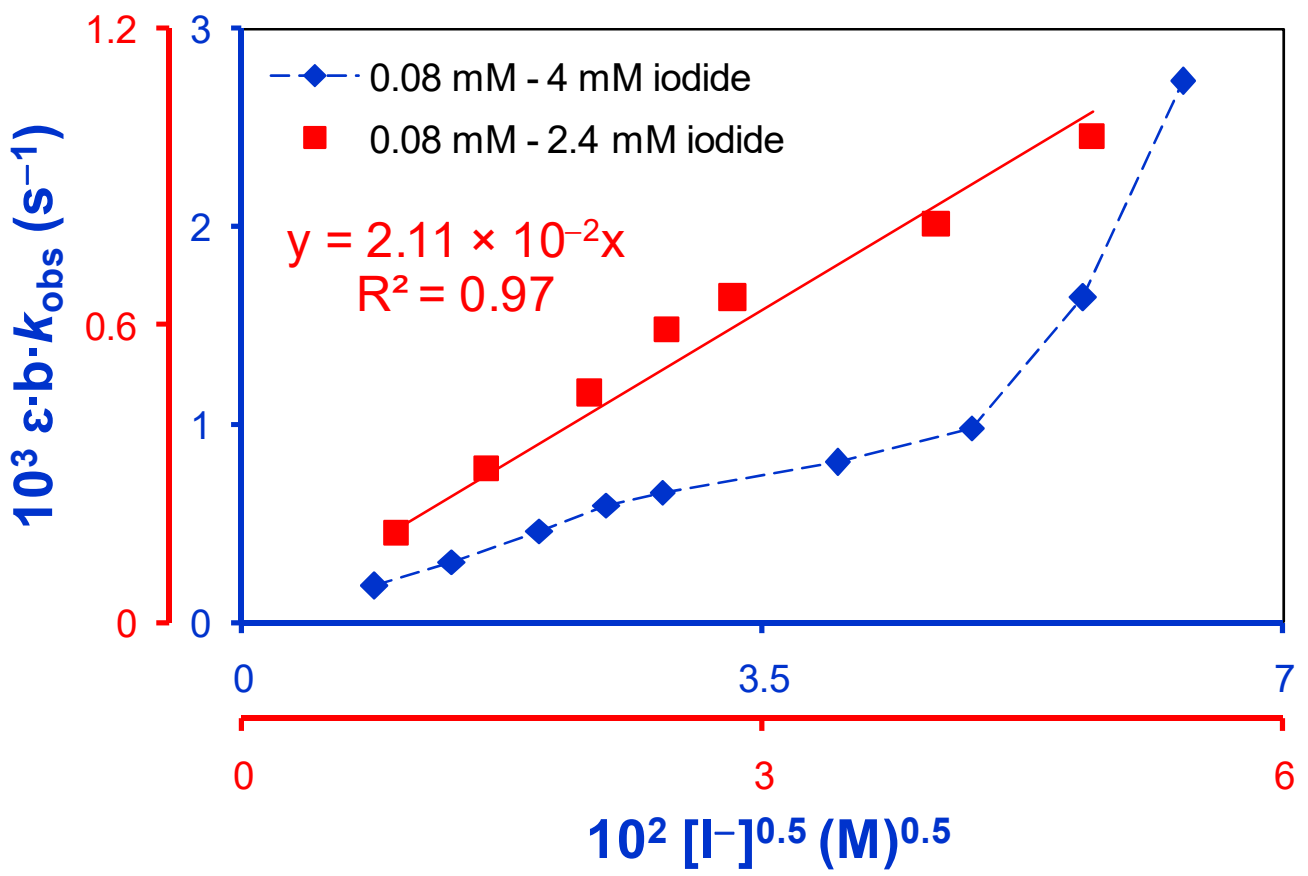

(b)

Figure 3. Cont. 


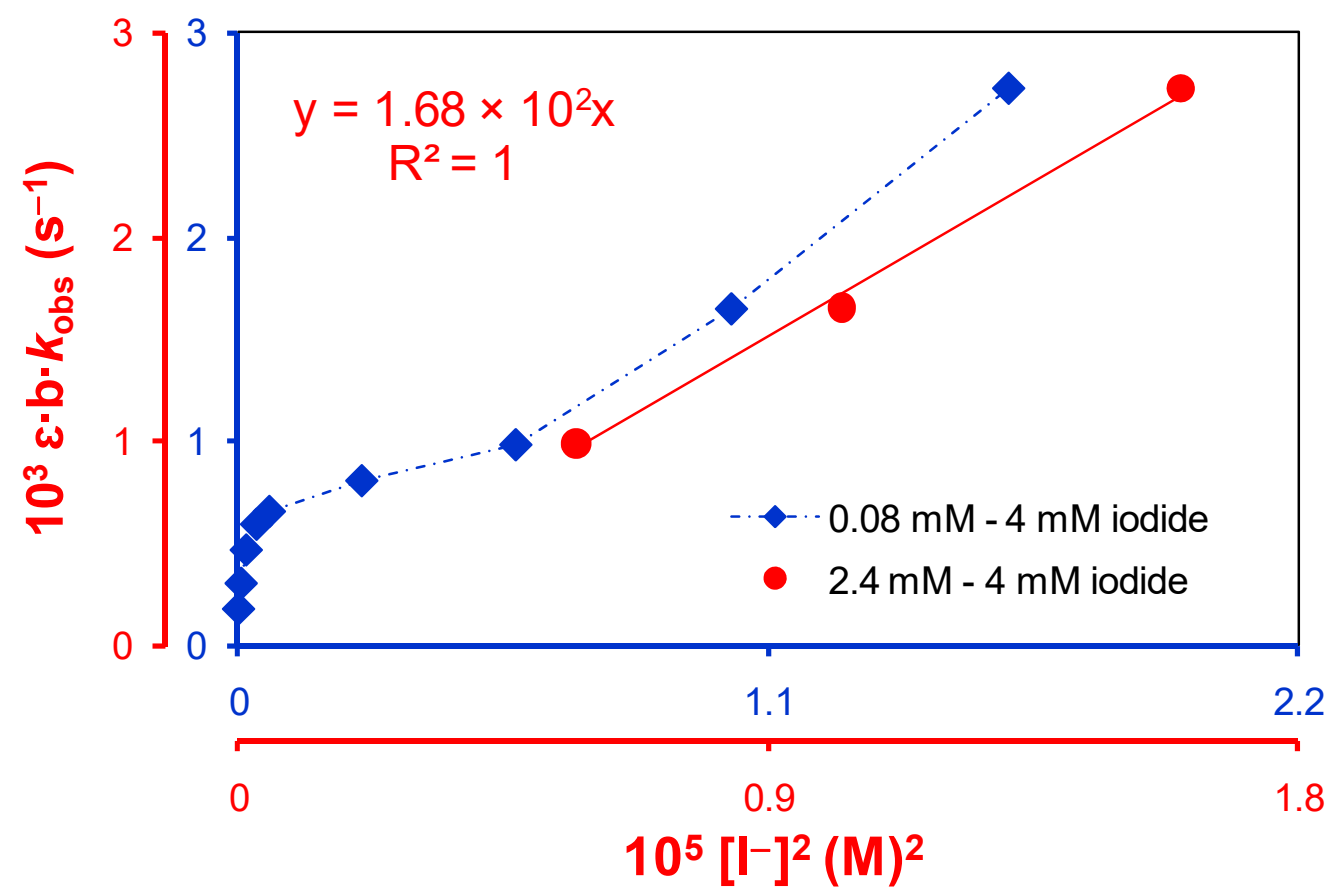

(c)

Figure 3. (a) Plot of the first order with respect to iodide. (b) Fractional (0.5) order plot with respect to iodide. (c) Second-order plot with respect to iodide.

The linear Equation (11) is used to get the value of the overall rate constant $(k)$, which is the reaction's second-order rate constant. When plotted between $k_{\mathrm{obs}}$ and the molar concentration of iodide on $y$ and $x$ coordinates, the linear line should pass through the origin and provide a slope with dimensions $\mathrm{M}^{-1} \mathrm{~s}^{-1}$. Similarly, for iodide oxidation in this study, zero, fractional, and second orders were identified with respect to dicyanobis(bipyridine)iron(III), iodide at moderate concentration, and iodide at quite high concentration, using Equations (1), (12) and (13).

- At moderate concentration of iodide:

$$
\text { Rate }=k\left[\mathrm{Fe}^{\mathrm{III}}(\mathrm{bpy})_{2}(\mathrm{CN})_{2}{ }^{+}\right]^{0}\left[\mathrm{I}^{-}\right]^{0.5}
$$

- At fairly high concentration of iodide:

$$
\text { Rate }=k \prime\left[\mathrm{Fe}^{\mathrm{III}}(\mathrm{bpy})_{2}(\mathrm{CN})_{2}\right]^{0}\left[\mathrm{I}^{-}\right]^{2} .
$$

Equations (18)-(20) are obtained by applying the pseudo-first-order condition i.e., $\left[\mathrm{Fe}^{\mathrm{III}}(\mathrm{bpy})_{2}(\mathrm{CN})_{2}{ }^{+}\right]<<<\left[\mathrm{I}^{-}\right]$, integration, the Beer-Lambert law, and then solving Equations (12) and (13).

$$
\begin{gathered}
\frac{\mathrm{d}\left[\mathrm{Fe}^{\mathrm{II}}(\mathrm{bpy})_{2}(\mathrm{CN})_{2}\right]}{\mathrm{dt}}=k\left[\mathrm{Fe}^{\mathrm{III}}(\mathrm{bpy})_{2}(\mathrm{CN})_{2}\right]^{+}\left[\mathrm{I}^{-}\right]^{0.5} \\
\frac{\mathrm{d}\left[\mathrm{Fe}^{\mathrm{II}}(\mathrm{bpy})_{2}(\mathrm{CN})_{2}\right]}{\mathrm{dt}}=k\left[\mathrm{Fe}^{\mathrm{III}}(\mathrm{bpy})_{2}(\mathrm{CN})_{2}\right]^{+}\left[\mathrm{I}^{-}\right]^{2} \\
\text { Since }\left[\mathrm{Fe}^{\mathrm{III}}(\mathrm{bpy})_{2}(\mathrm{CN})_{2}\right]^{+}=1
\end{gathered}
$$




$$
\begin{gathered}
\frac{\mathrm{d}\left[\mathrm{Fe}^{\mathrm{II}}(\mathrm{bpy})_{2}(\mathrm{CN})_{2}\right]}{\mathrm{dt}}=k_{\mathrm{obs}} \\
{\left[\mathrm{Fe}^{\mathrm{II}}(\mathrm{bpy})_{2}(\mathrm{CN})_{2}\right]_{\mathrm{t}}=\left[\mathrm{Fe}^{\mathrm{II}}(\mathrm{bpy})_{2}(\mathrm{CN})_{2}\right]_{0}+k_{\mathrm{obs}} \cdot \mathrm{t}}
\end{gathered}
$$

In terms of increase in absorbance upon the formation of dicyanobis(bipyridine)iron(II), Equation (17) becomes Equation (18).

$$
\frac{1}{\varepsilon \cdot b} \cdot\left([\mathrm{A}]_{\mathrm{t}}-[\mathrm{A}]_{0}\right)=k_{\mathrm{obs}} \cdot \mathrm{t}
$$

Equations (1) and (18) are equivalent if $\epsilon \cdot b$ in the denominator and the negative value of $[\mathrm{A}]_{0}$ on the left-hand side of Equation (18) are rearranged to the numerator and positive value of $[\mathrm{A}]_{0}$ on the right-hand side. This rearrangement yields Equation (1), which we used to determine the value of $\epsilon \cdot \mathrm{b} \cdot k_{\mathrm{obs}}$ in $\mathrm{s}^{-1}$ at different concentrations of iodide in water. The values of the slope $\left(\epsilon \cdot \mathrm{b} \cdot k_{\mathrm{obs}}\right)$ at different and excess concentrations of iodide were plotted against the molar concentration of iodide to obtain a linear plot passing through the origin. The linear fit of the plot helped to identify the order of reaction with respect to the iodide ion at moderate and high concentration range, and the slope yielded the overall rate constant of the reaction according to Equations (19) and (20).

$$
\begin{aligned}
& \varepsilon \cdot \mathrm{b} \cdot k_{\mathrm{obs}}=\varepsilon \cdot \mathrm{b} \cdot k \cdot\left[\mathrm{I}^{-}\right]^{0.5} \\
& \varepsilon \cdot \mathrm{b} \cdot k_{\mathrm{obs}}=\varepsilon \cdot \mathrm{b} \cdot k \cdot\left[\mathrm{I}^{-}\right]^{2}
\end{aligned}
$$

\subsubsection{Active Reactants of the Rate-Determining Step of Uncatalyzed Reaction}

Iodide is very well known to produce triiodide ion, protonated iodide, and protonated triiodide molecules. However, dicyanobis(bipyridine)iron(III) is a substitution inert outersphere oxidant that does not produce any other corresponding species, including its protonation, which is impossible under the experimental conditions we employed herein this study. The following equilibria may exist in the reaction vessel (Equations (21)-(23)).

$$
\begin{gathered}
\mathrm{I}^{-}+\mathrm{I}_{2} \stackrel{\mathrm{K}_{1}}{\leftrightarrow} \mathrm{I}_{3}^{-} \\
\mathrm{H}^{+}+\mathrm{I}^{-} \stackrel{\mathrm{K}_{2}}{\leftrightarrow} \mathrm{HI} \\
\mathrm{H}^{+}+\mathrm{I}_{3}^{-} \stackrel{\mathrm{K}_{3}}{\leftrightarrow} \mathrm{HI}_{3}
\end{gathered}
$$

To identify the active reactant among iodide, triiodide, protonated iodide, and protonated triiodide, the effect of variation in the concentration of protons was studied on the observed zero-order rate constant. The equilibrium between iodide and protonated iodide may hardly be possible because the dissociation constant of $\mathrm{HI}$ is very high. In order to rectify our results, the kinetics of the reaction was probed at increasing concentrations of nitric acid $\left(\mathrm{HNO}_{3}\right)$ within the range from neutral $\mathrm{pH}$ (i.e., without the addition of nitric acid) to $0.1 \mathrm{M}$ nitric acid. The experimental conditions such as the concentration of oxidant $(0.08 \mathrm{mM})$ and reductant $(0.8 \mathrm{mM})$ were constant at $0.11 \mathrm{M}$ ionic strength and $290 \pm 0.5 \mathrm{~K}$ to draw the results of the effect of protons on the rate constant. The ionic strength was maintained by potassium nitrate $\left(\mathrm{KNO}_{3}\right)$. The value of $\epsilon \cdot \mathbf{b} \cdot k_{\mathrm{obs}}$ declined gradually as the concentration of protons increased up to $0.01 \mathrm{M} \mathrm{H}^{+}\left(\mathrm{HNO}_{3}\right)$; then, it increased at $0.1 \mathrm{M} \mathrm{H}^{+}$ $\left(\mathrm{HNO}_{3}\right)$. The results show that the unprotonated iodide or triiodide ion controls the slowstep of the reaction by donating an electron to dicyanobis(bipyrididne)iron(III) (Figure 4a). Therefore, the protonation of these species reduced their concentration in the vicinity and reduced the value of the rate constant, consequently. Here, it is worthwhile to consider that the dissociation constant of $\mathrm{HI}$ is known to be fairly high. If iodide is expected to be the active reactant among iodide and triiodide ions that leads the slow-step of the reaction, then increasing the concentration of protons $\left(\mathrm{H}^{+}\right)$in the reaction mixture to $0.1 \mathrm{M} \mathrm{HNO}_{3}$ 
should have reduced the rate of reaction and/or the rate constant. Since the concentration of protons increases, the equilibrium (22) moves forward, motivating the protonation of iodide to form $\mathrm{HI}$, which should result in a drop in the concentration of rate-controlling iodide and, as a result, a fall in the rate constant's value. However, our findings show that adding nitric acid to the reaction vessel lowered the rate of the reaction to some extent, and adding excess nitric acid $(0.1 \mathrm{M})$ increased it. The findings pinpoint the active species in the rate-determining step of iodide oxidation by dicyanobis(bipyridine)iron(III) in water as triiodide $\left(\mathrm{I}_{3}{ }^{-}\right)$ion (Equations (24) and (25)) rather than iodide. Iodide was oxidized by dicyanobis(bipyridine)iron(III) in the fast-step of the reaction (Equation (2)), which resulted in iodine that interacted with iodide in the vicinity to create triiodide ions (Equation (21)). These triiodide ions were involved in the reaction's rate-determining step. Since $\mathrm{HI}_{3}$ is a weak acid in comparison to HI, the equilibrium (23) is expected to have a low dissociation constant. At $0.01 \mathrm{M} \mathrm{H}^{+}$ions, the reaction (Equation (23)) maintained equilibrium, and further protonated triiodide production appeared to be halted. As a result, additional protons did not diminish the concentration of maximum accessible triiodide ion in the reaction vessel; rather, interionic repulsive forces between the same charge carriers, such as cations, supported the interaction between triiodide ion and dicyanobis(bipyridine)iron(III) in the slow-step of the reaction (Equations (24) and (25)). Using NOx as an oxidant, the oxidation of triiodide ion has previously been described [67]. The oxidation of iodide and triiodide occurs when the concentration of $\mathrm{HNO}_{3}$ exceeds $1 \mathrm{~N}$, according to the same study and yields iodine as the product of the reaction (Equation (24)).

$$
\begin{gathered}
2 \mathrm{I}_{3}^{-} \rightarrow 3 \mathrm{I}_{2}+2 \overline{\mathrm{e}} \\
2\left[\mathrm{Fe}^{\mathrm{III}}(\mathrm{bpy})_{2}(\mathrm{CN})_{2}\right]^{+}+2 \mathrm{I}_{3}^{-}+2 \overline{\mathrm{e}} \rightarrow 2\left[\mathrm{Fe}^{\mathrm{II}}(\mathrm{bpy})_{2}(\mathrm{CN})_{2}\right]+3 \mathrm{I}_{2}+2 \overline{\mathrm{e}}
\end{gathered}
$$

A straight line was drawn by plotting the reciprocal of rate constant $\left(\epsilon \cdot \mathrm{b} \cdot k_{\mathrm{obs}}\right)$ on the $y$-axis against the fractional $(0.25)$ power of protons concentration $\left(1 \times 10^{-7}-0.01 \mathrm{M}\right)$ on the $x$-axis (Figure $4 \mathrm{~b}$ ). The slope of the figure is equivalent to the value of the proton-dependent inverse fractional order rate constant $\left(2.59 \times 10^{3} \mathrm{M}^{-0.25} \mathrm{~s}\right)$, whereas the intercept displays the reciprocal of the proton-independent observed rate constant. The findings confirmed triiodide as the active species in the rate-limiting stage of the redox process.

For further rectification of the results, the effect of ionic strength on the observed zero-order rate constant was studied. Equation (26) is the formulation of the transition state theory of reactions in solution that correlates the rate constant with the ionic strength.

$$
\log k=\log k_{0}+1.02 \mathrm{z}_{\mathrm{A}} \mathrm{Z}_{\mathrm{B}} \sqrt{\mu}
$$

The intercept of the plot determines the value of the rate constant at zero ionic strength according to Equation (26). This is a theoretical value that illustrates the effect of the dielectric constant or medium of the reaction on the rate constant, excluding the effect of existing ions in the vicinity. The slope of the plot helps to identify the active participants of the reaction that form the transition state complex while the reaction medium is water. Here, 1.02 is a constant value for water at $25^{\circ} \mathrm{C}$ and $\mathrm{z}_{\mathrm{A}} \mathrm{z}_{\mathrm{B}}$ are the charges on the reactants that form the transition state complex. From the value of the slope of the plot, we can determine the interaction between the ions or molecules that lead the reaction mechanism. While the reactants carry opposite electrical charges, we should have obtained a negative value of the slope with a corresponding multiplication product of the charges on the reactants $\mathrm{z}_{\mathrm{A}} \mathrm{z}_{\mathrm{B}}$ as the magnitude of the slope in water. When the similar charge carriers form the transition state complex and lead the reaction mechanism, the positive value of the slope should have been obtained with the corresponding magnitude of the multiplication product of the electrical charges. However, the transition state complex formation between ion-molecule and or molecule-molecule yields a zero value of the slope with no effect of ionic strength on the rate constant. 


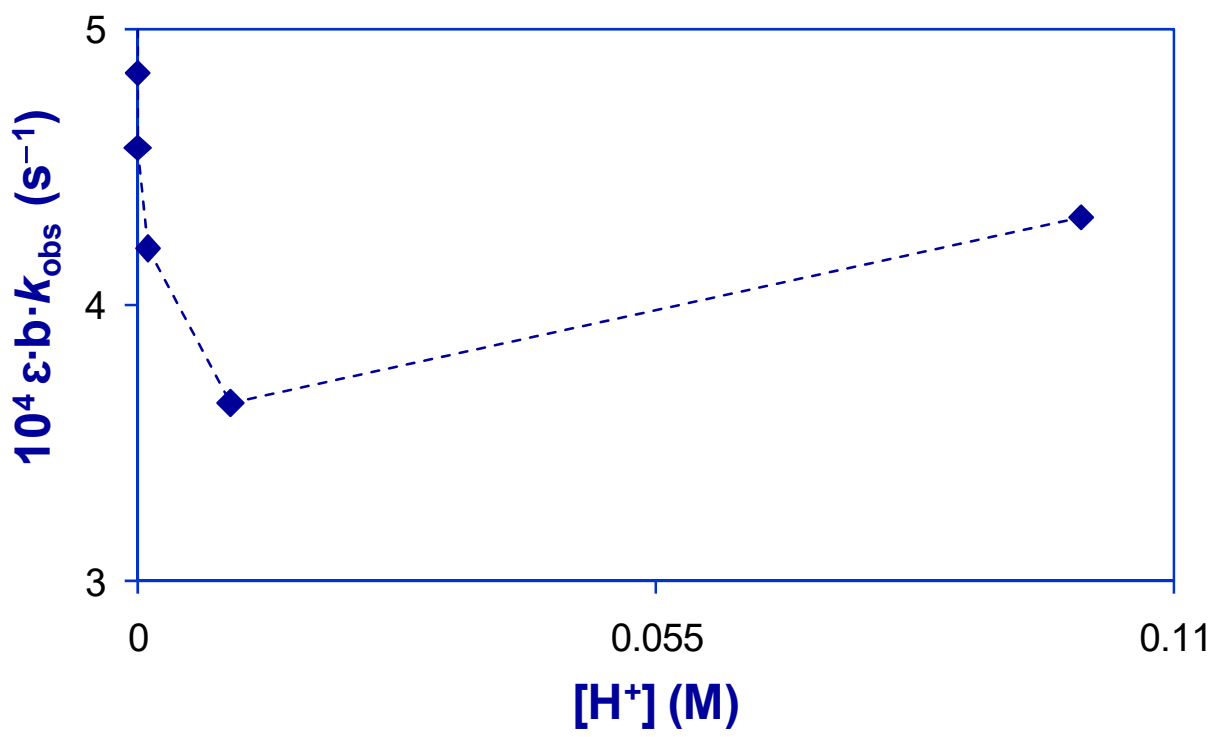

(a)

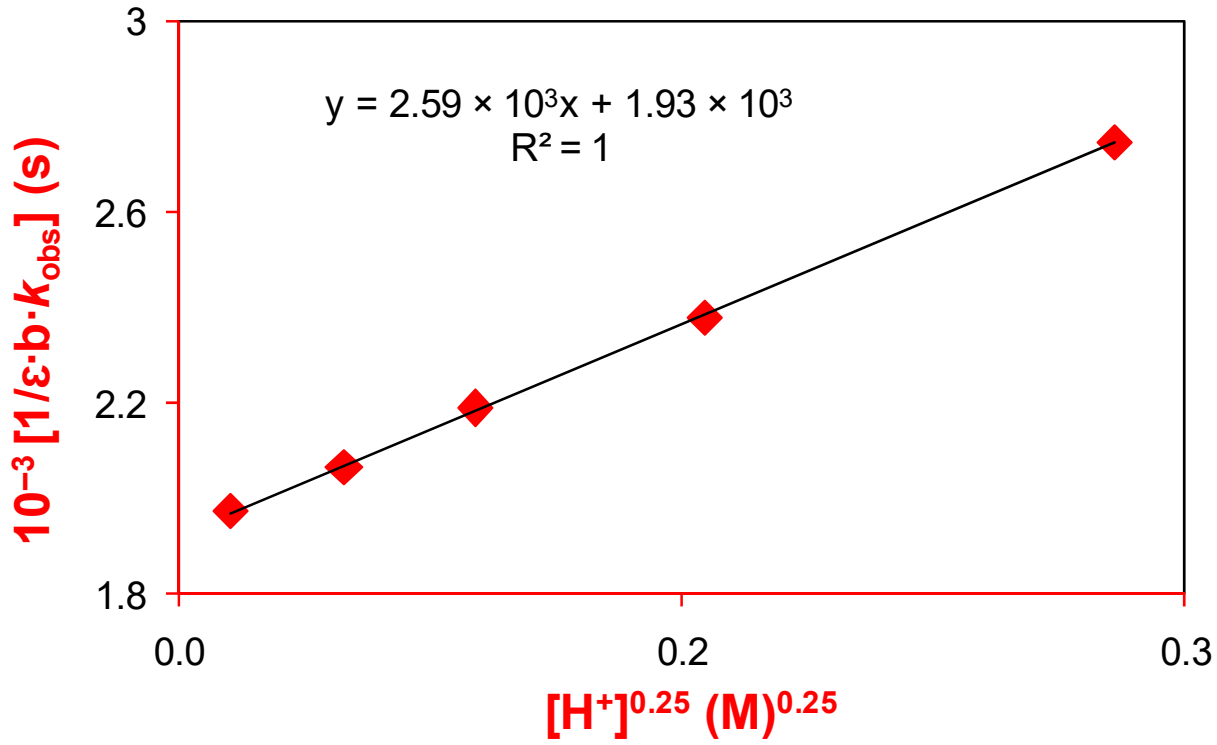

(b)

Figure 4. (a) Plot illustrating the rate constant as a function of rising proton concentration. (b) Inverse fractional $(0.25)$ order plot with respect to proton $\left(\mathrm{H}^{+}\right)$.

If we carefully review our results, we observe that the primary reactant i.e., iodide ion, was not involved in the rate-determining step (Equation (25)); rather, it led the fast-step of the reaction (Equation (2)). It formed triiodide ion upon reaction with iodine, and the equilibrium was established between iodide and triiodide ions (Equation (21)) in the reaction mixture. Essentially, iodine was the limiting reactant, which controlled the overall reaction mechanism by producing triiodide ion. The production of triiodide ion depended upon the concentration of iodine that was produced during the reaction and the equilibrium constant $\left(\mathrm{K}_{1}\right)$. Then, the triiodide ion interacted with dicyanobis(bipyridine)iron(III) during the slow-step of the reaction. As a result, we conclude that because iodide was not involved in the rate-determining step, iodine was the reactant that formed the transition state complex with dicyanobis(bipyridine)iron(III) and subsequently led the reaction mechanism by creating triiodide ion following interaction with iodide. However, the reaction should not show any effect of variation in the ionic strength on the rate constant because of the interaction between monopositive oxidant and neutral iodine. We rearranged Equa- 
tion (26) to Equation (27) for the kinetic parameters of our investigation in order to confirm our findings.

$$
\log \left(\varepsilon \cdot b \cdot k_{\mathrm{obs}}\right)=\log \varepsilon \cdot \mathrm{b} \cdot\left(k_{\mathrm{obs}}\right)_{0}+1.02 \mathrm{z}_{\mathrm{A}} \mathrm{z}_{\mathrm{B}} \sqrt{\mu}
$$

To determine the effect of ionic strength on $\epsilon \cdot b \cdot k_{\text {obs }}$, the time course graph was obtained at different values of the ionic strength by keeping other experimental parameters constant. The concentration of oxidant and reductant were fixed at $0.08 \mathrm{mM}$ and $0.8 \mathrm{mM}$, respectively. The reaction was probed at $289 \pm 0.5 \mathrm{~K}$ in aqueous medium, and the ionic strength was increased from 0.005 to $0.37 \mathrm{M}$ by adding potassium nitrate to the reaction mixture. The graph was plotted between the $\log _{10}\left(\epsilon \cdot \mathrm{b} \cdot k_{\mathrm{obs}}\right)$ (i.e., determined at each value of the ionic strength) and the square root of the value of ionic strength according to Equation (27). The results are illustrated in Figure 5. We did not observe any effect of variation in the ionic strength on the observed rate constant, which confirmed that the transition state complex was formed between monopositive dicyanobis(bipyridine)iron(III) i.e., $\left[\mathrm{Fe}^{\mathrm{III}}(\mathrm{bpy})_{2}(\mathrm{CN})_{2}\right]^{+}$, and neutral iodine $\left(\mathrm{I}_{2}\right)$.

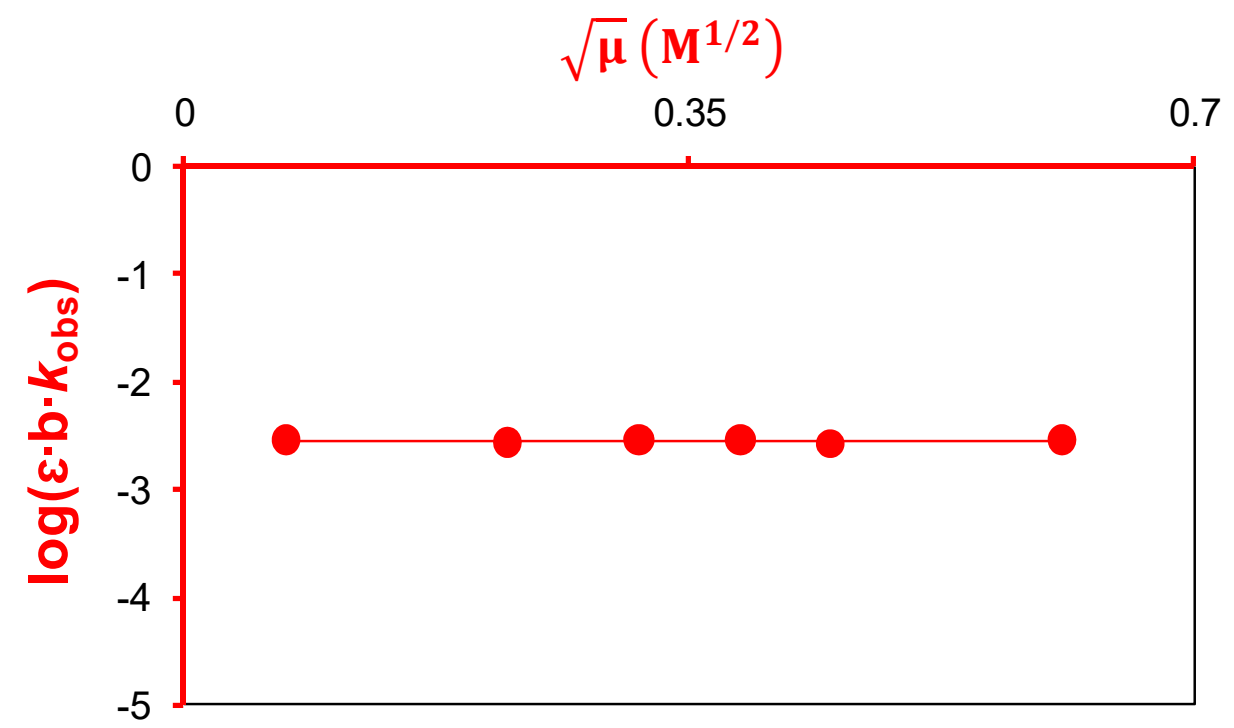

Figure 5. Plot of the effect of ionic strength on the observed rate constant.

\subsubsection{Thermodynamic Parameters of Activation}

The thermodynamic parameters of activation were determined for the uncatalyzed oxidation of iodide by dicyanobis(bipyridine)iron(III) in water. The temperature was varied and the time course graph was probed at each temperature by keeping all other experimental parameters constant. The concentrations of the oxidant, reductant, and ionic strength were maintained constant at $0.08 \mathrm{mM}, 0.8 \mathrm{mM}$, and $0.06 \mathrm{M}$, respectively. The ionic strength was preserved by adding potassium nitrate to the reaction mixture. The value of the observed zero-order rate constant $\left(\epsilon \cdot \mathrm{b} \cdot k_{\mathrm{obs}}\right)$ was evaluated at each temperature, and the thermodynamic parameters of activation were determined by applying Arrhenius and Eyring Equations (28), (29) and (30), respectively.

$$
\begin{gathered}
k=\mathrm{Ae}^{-\frac{\mathrm{E}_{\mathrm{a}}}{\mathrm{RT}}} \\
k=\frac{\kappa \mathrm{k}_{\mathrm{B}} \mathrm{T}}{\mathrm{h}} \mathrm{e}^{-\frac{\Delta \mathrm{H}^{\#}}{\mathrm{RT}}} \mathrm{e}^{\frac{\Delta \mathrm{S}^{\#}}{\mathrm{R}}}
\end{gathered}
$$

or,

$$
\frac{k}{\mathrm{~T}}=\frac{\kappa \mathrm{k}_{\mathrm{B}}}{\mathrm{h}} \mathrm{e}^{-\frac{\Delta \mathrm{H}^{\#}}{\mathrm{RT}}} \mathrm{e}^{\frac{\Delta \mathrm{S}^{\#}}{\mathrm{R}}}
$$

In Equations (28)-(30), $k, \mathrm{~A}, \mathrm{E}_{\mathrm{a}}, \mathrm{R}, \mathrm{T}, \mathrm{\kappa}, \mathrm{k}_{\mathrm{B}}, \mathrm{h}, \Delta \mathrm{H}^{\#}$ and $\Delta \mathrm{S}^{\#}$ have conventional meanings such as rate constant, pre-exponential factor, activation energy, universal gas constant, 
Kelvin temperature, transmission coefficient (generally taken to be mathematical figure ' 1 '), Boltzmann constant, Planck's constant, enthalpy change of activation, and entropy change of activation, respectively. Equations (28) and (30) can be rearranged to linear Equations (31) and (34), respectively, to draw plots and to estimate the activation parameters. The values of $\mathrm{b}$ (path length of quartz cuvette) and $\epsilon$ (molar absorptivity of $\left[\mathrm{Fe}^{\mathrm{II}}(\mathrm{bpy})_{2}(\mathrm{CN})_{2}\right]$ in water) are $1 \mathrm{~cm}$ and $\approx 4388 \mathrm{M}^{-1} \mathrm{~cm}^{-1}$, respectively.

$$
\begin{gathered}
\ln \left(\varepsilon \cdot \mathrm{b} \cdot k_{\mathrm{obs}}\right)=\ln (\varepsilon \cdot \mathrm{b} \cdot \mathrm{A})-\frac{\mathrm{E}_{\mathrm{a}}}{\mathrm{R}} \cdot \frac{1}{\mathrm{~T}} \\
\frac{\varepsilon \cdot \mathrm{b} \cdot k_{\mathrm{obs}}}{\mathrm{T}}=\frac{\varepsilon \cdot \mathrm{b} \cdot \mathrm{k} \cdot \mathrm{k}_{\mathrm{B}}}{\mathrm{h}} \mathrm{e}^{-\frac{\Delta \mathrm{H}^{\#}}{\mathrm{RT}}} \mathrm{e}^{\frac{\Delta \mathrm{S}^{\#}}{\mathrm{R}}} \\
\ln \frac{\varepsilon \cdot \mathrm{b} \cdot k_{\mathrm{obs}}}{\mathrm{T}}=\ln \frac{\varepsilon \cdot \mathrm{b} \cdot \mathrm{k} \cdot \mathrm{k}_{\mathrm{B}}}{\mathrm{h}}+\frac{\Delta \mathrm{S}^{\#}}{\mathrm{R}}-\frac{\Delta \mathrm{H}^{\#}}{\mathrm{RT}} \\
\ln \frac{\varepsilon \cdot \mathrm{b} \cdot k_{\mathrm{obs}}}{\mathrm{T}}=32.146+\frac{\Delta \mathrm{S}^{\#}}{\mathrm{R}}-\frac{\Delta \mathrm{H}^{\#}}{\mathrm{R}} \cdot \frac{1}{\mathrm{~T}}
\end{gathered}
$$

A plot of $\ln \left(\epsilon \cdot \mathrm{b} \cdot k_{\mathrm{obs}}\right)$ was drawn against $1 / \mathrm{T}$ that yielded intercept and slope with $99 \%$ linear fit $\left(R^{2}\right.$ value 0.99$)$, as shown in Figure 6a. The values of $A\left(24.62 \mathrm{M} \mathrm{s}^{-1}\right)$ and $E_{a}\left(46.23 \mathrm{~kJ} \mathrm{~mol}^{-1}\right)$ were calculated from the intercept and the slope of the plot, respectively. Meanwhile, a linear plot between $\ln \left(\epsilon \cdot \mathrm{b} \cdot k_{\mathrm{obs}} / \mathrm{T}\right)$ and $1 / \mathrm{T}$ helped to calculate $\Delta \mathrm{S}^{\#}\left(-226.5 \mathrm{~J} \mathrm{~mol}^{-1} \mathrm{~K}^{-1}\right)$ and $\Delta \mathrm{H}^{\#}\left(43.76 \mathrm{~kJ} \mathrm{~mol}^{-1}\right)$ from the intercept and the slope of the plot, respectively (Figure $6 \mathrm{~b}$ ). The Gibbs free energy of activation $\left(\Delta \mathrm{G}^{\#}\right)$ was also determined by using Equation (35) and found $111.26 \mathrm{~kJ} \mathrm{~mol}^{-1}$ at $25^{\circ} \mathrm{C}$.

$$
\Delta \mathrm{G}^{\#}=\Delta \mathrm{H}^{\#}-\mathrm{T} \Delta \mathrm{S}^{\#}
$$

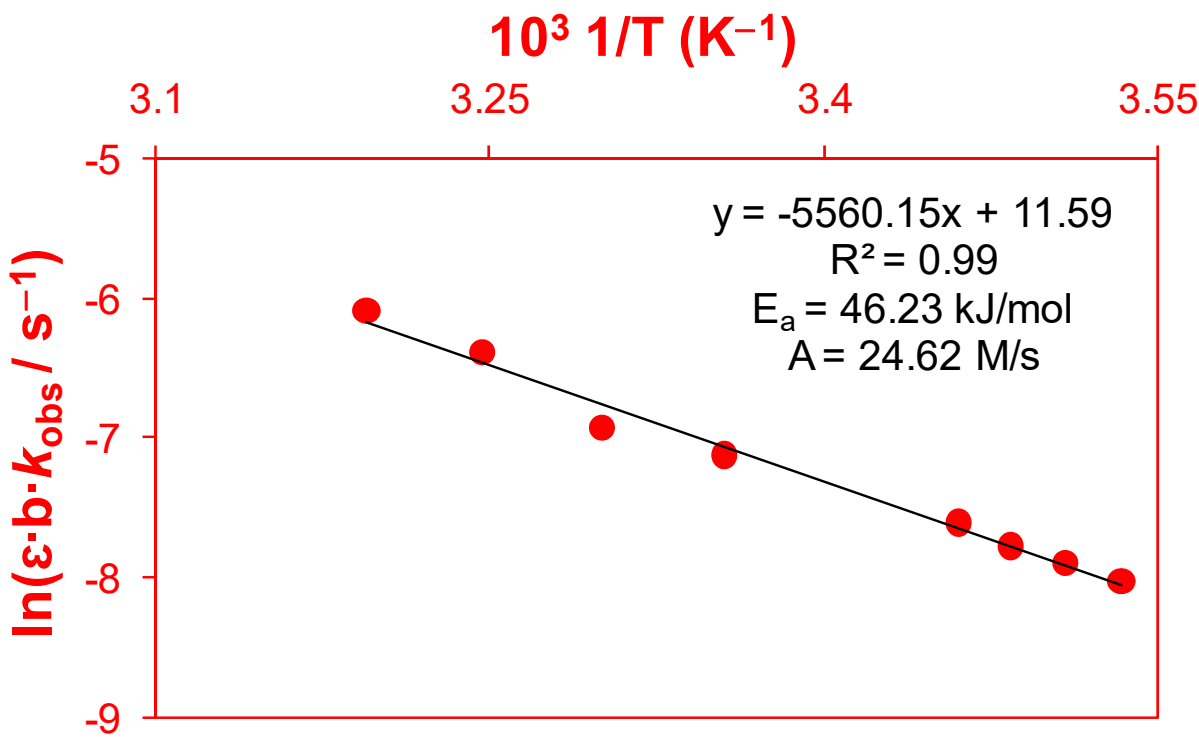

(a)

Figure 6. Cont. 


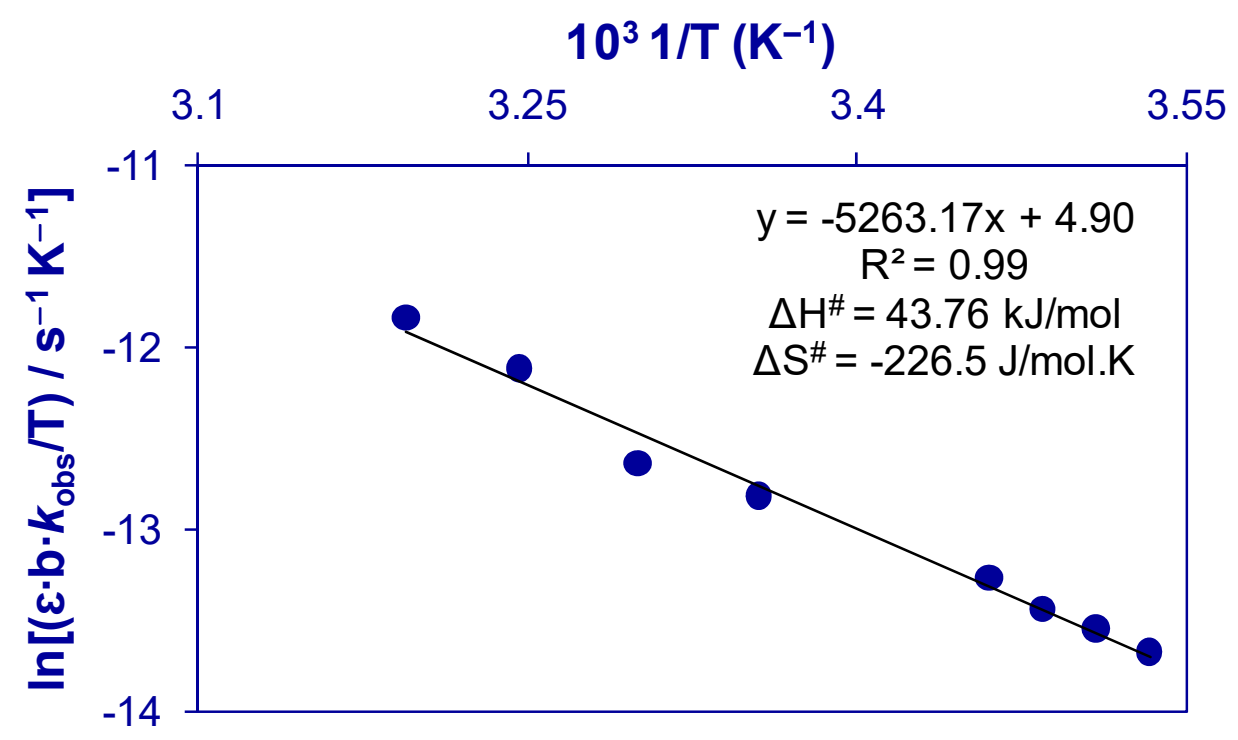

(b)

Figure 6. (a)Arrhenius plot. (b) Eyring plot.

\subsection{Kinetic Parameters of 1,4-Dioxane Catalyzed Reaction}

The catalyzed reaction was monitored in the same way as the uncatalyzed reaction. Only the reaction media were different. The catalyzed reaction was studied in two reaction media: i.e., $10 \%(v / v)$ 1,4-dioxane-water and $20 \%(v / v)$ 1,4-dioxane-water. For the uncatalyzed reaction, all the experimental parameters were maintained and/or varied in water. However, for the catalyzed reaction, the entire process, including the concentration of constant and varying experimental parameters, was identical to that of the uncatalyzed reaction, albeit in media containing $10 \%$ and $20 \%$ 1,4-dioxane-water rather than water. As a result, the experimental parameters will not be provided in the next section, and only the results or outcomes will be presented and discussed.

\subsubsection{Overall Order of Reaction and the Overall Rate Constant of Catalyzed Reaction}

Similar to the uncatalyzed reaction, the catalyzed reaction followed zero order with respect to dicyanobis(bipyridine)iron(III) in $10-20 \%$ dioxane-water. The catalysis was observed upon the addition of 1,4-dioxane to water. The order of reaction with respect to iodide was identified to be first and third in 10\% (Figure 7a) and 20\% $(v / v)$ dioxane-water (Figure $7 \mathrm{~b}, \mathrm{c}$ ), respectively. The reaction is considered in its maximum rate while the rate of reaction depends upon the third power of a concentration term involved in the rate law. The third power dependence corresponds to the third-order reaction i.e., the maximum rate of a reaction. Our results show that in $10 \%$ dioxane-water, the reaction rate is double; i.e., it is overall first order as compared to the uncatalyzed reaction where it followed an overall fractional (0.5) order in water medium. The slope of the plot produces an overall first-order rate constant $(\epsilon \cdot \mathrm{b} \cdot k)$ as $4.438 \mathrm{M}^{-1} \mathrm{~s}^{-1}$ (Figure 7a), according to Equation (36).

$$
\varepsilon \cdot \mathrm{b} \cdot k_{\mathrm{obs}}=\varepsilon \cdot \mathrm{b} \cdot k\left[\mathrm{I}^{-}\right]
$$




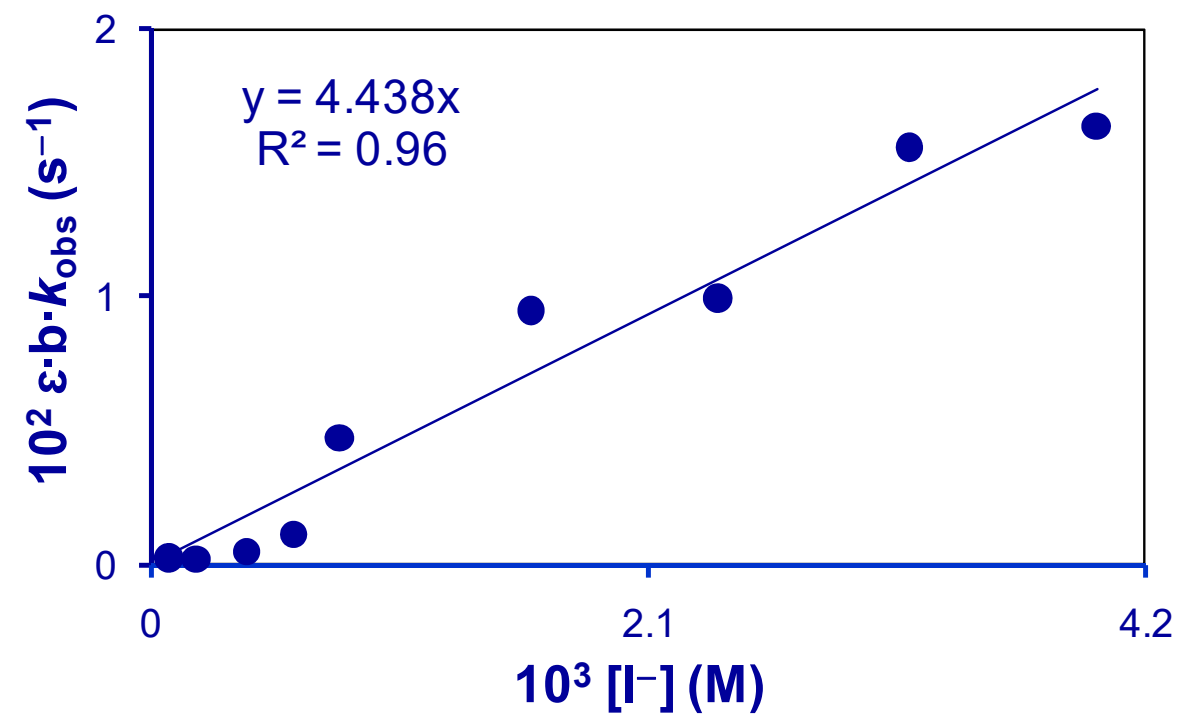

(a)

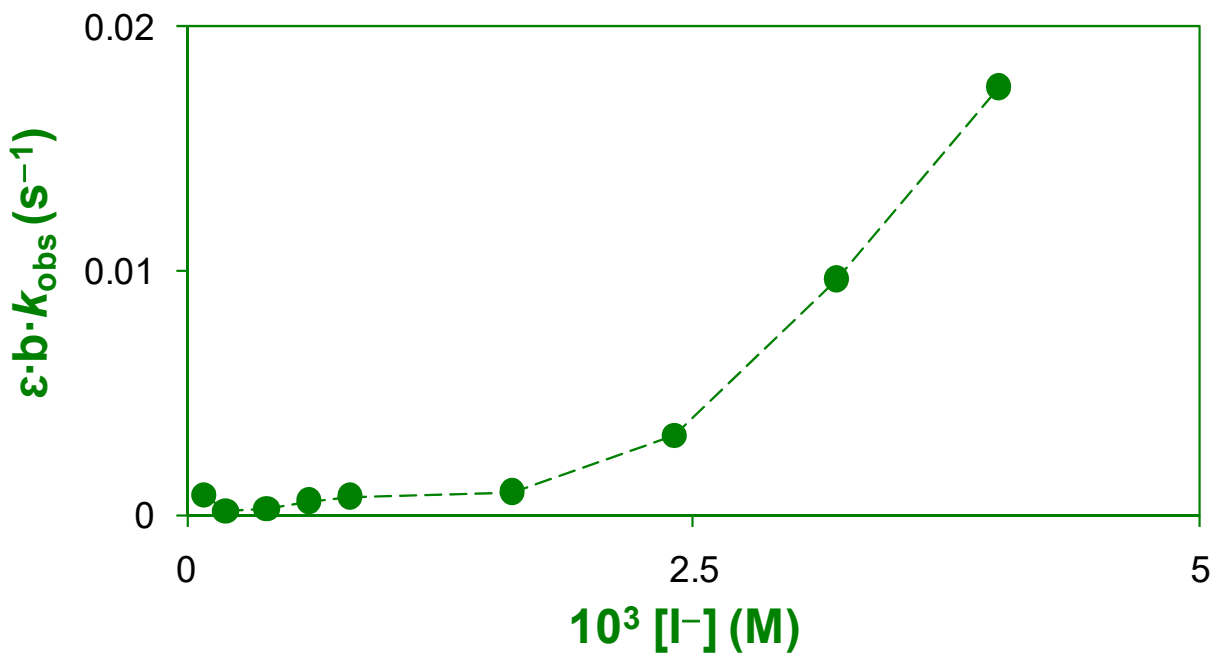

(b)

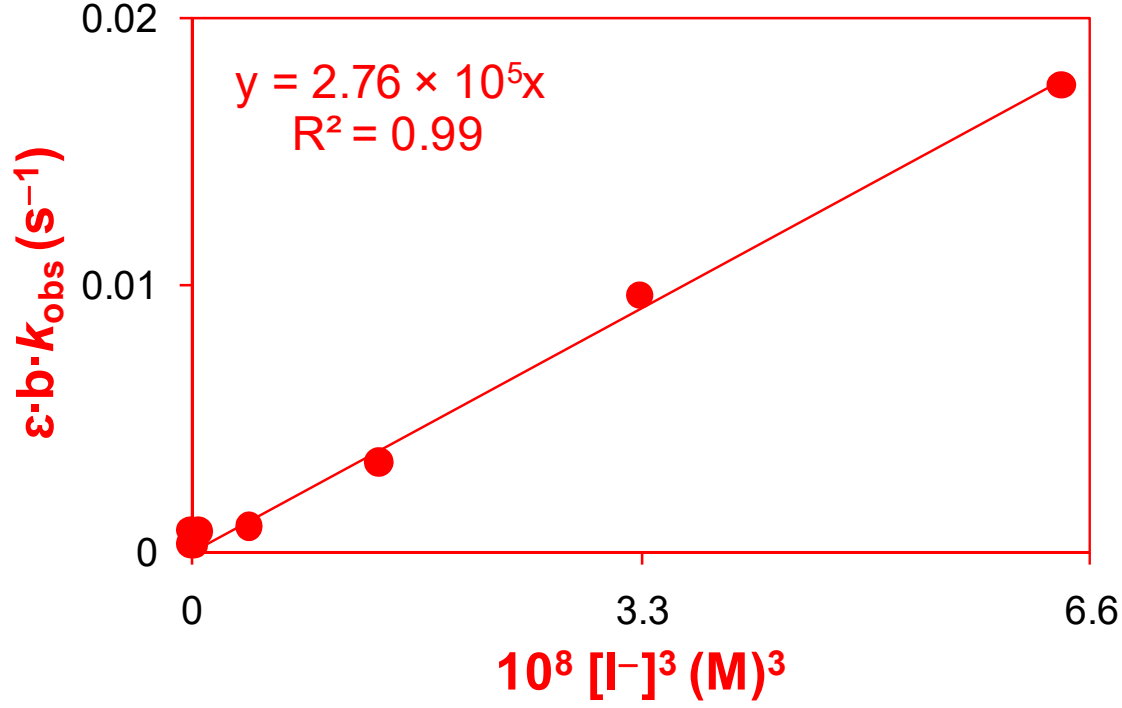

(c)

Figure 7. (a) Plot of first order with respect to iodide in $10 \% v / v$ dioxane-water at $293 \pm 0.5 \mathrm{~K}$. (b) Plot of first order with respect to iodide in $20 \% v / v$ dioxane-water at $284 \pm 0.5 \mathrm{~K}$. (c) Third-order plot with respect to iodide in $20 \% v / v$ dioxane-water at $284 \pm 0.5 \mathrm{~K}$. 
However, in 20\% dioxane-water, where the reaction followed an overall third-order kinetics, the reaction attained its maximal rate by rapidly completing. According to the data (Figure $7 \mathrm{c}$ ), the oxidation of iodide by dicyanobis(bipyridine)iron(III) reaches its highest rate in $20 \%$ binary solvent system, with an overall rate constant $(\epsilon \cdot b \cdot k) 2.76 \times 10^{5} \mathrm{M}^{-3} \mathrm{~s}^{-1}$ according to Equation (37).

$$
\varepsilon \cdot \mathrm{b} \cdot k_{\mathrm{obs}}=\varepsilon \cdot \mathrm{b} \cdot k\left[\mathrm{I}^{-}\right]^{3}
$$

\subsubsection{Active Reactants of the Rate-Determining Step of Catalyzed Reaction}

The effect of additional protons such as nitric acid was probed on the observed zero-order rate constant by maintaining all the experimental parameters similar to the uncatalyzed reaction in $10 \%$ and $20 \%(v / v) 1,4$-dioxane-water rather than $100 \%$ water. The results reveal that raising the concentration of protons has a catalytic effect on the rate constant in both binary solvent media (Figure 8a,c). Within the concentration range of externally injected protons $\left(\mathrm{HNO}_{3}\right)$, such as $1 \mathrm{mM}$ to $0.1 \mathrm{M}$ (red data in Figure $8 \mathrm{a}$ ), the value of $\epsilon \cdot \mathrm{b} \cdot k_{\mathrm{obs}}$ grew linearly, with an increasing curvature below $1 \mathrm{mM}$ in $10 \%$ binary solvent media. The linear plot yields the proton catalyzed rate constant; $8.99 \times 10^{-4} \mathrm{M}^{-1} \mathrm{~s}^{-1}$ (slope) and the proton independent rate constant $2.69 \times 10^{-4} \mathrm{~s}^{-1}$ (intercept). If we divide $\mathrm{M}^{-1} \mathrm{~s}^{-1}$ by the dimension of $\epsilon \cdot \mathrm{b}\left(\mathrm{M}^{-1} \mathrm{~cm}^{-1} \mathrm{~cm}\right)$, the proton catalytic rate constant can be used to identify the first order in proton $\left(\mathrm{H}^{+}\right)$throughout the range of $1 \mathrm{mM}$ to $0.1 \mathrm{M}$. Meanwhile, when the externally injected protons concentration is less than $1 \mathrm{mM}$, the $\log -\log$ plot of the rate constant and proton yields a straight line with a 0.076 ' $n$ ' value, which represents the order of reaction according to Equation (39) (Figure 8b).

$$
\begin{gathered}
\varepsilon \cdot \mathrm{b} \cdot k_{\text {obs }}=\varepsilon \cdot \mathrm{b} \cdot k \cdot\left[\mathrm{H}^{+}\right]^{\mathrm{n}} \\
\log \left(\varepsilon \cdot \mathrm{b} \cdot k_{\mathrm{obs}}\right)=\log (\varepsilon \cdot \mathrm{b} \cdot k)+\mathrm{n} \log \left[\mathrm{H}^{+}\right]
\end{gathered}
$$

In Equations (38) and (39), $\epsilon \cdot b \cdot k$ is the multiplication product of $\epsilon \cdot b$. with the protonindependent observed zero-order rate constant. We obtained similar results in $20 \%$ binary solvent media with a straight line plot between $\log \left(\epsilon \cdot \mathrm{b} \cdot k_{\mathrm{obs}}\right)$ and $\log \left[\mathrm{H}^{+}\right]$with 0.15 ' $\mathrm{n}$ ' value at below $1 \mathrm{mM}$ concentration of externally injected protons (Figure $8 \mathrm{~d}$ ). However, as the concentration of protons increased above $1 \mathrm{mM}-0.1 \mathrm{M}$, the value of the observed zero-order rate constant decreased and became constant at high concentration (Figure 8c). A detailed examination of Figure $8 \mathrm{c}$ reveals that the values of the rate constant at $0.01 \mathrm{M}$ and $0.1 \mathrm{M}$ additional proton $\left(\mathrm{H}^{+}\right)$are nearly identical to the rate constant without any external proton/acid addition. When contrasted to water as a medium, this highlights the strong hydrogen bonding between 1,4-dioxane and water, which aids in achieving equilibrium (23) at low proton concentrations. The results of protons' influence in binary solvent media of $10 \%$ and $20 \%$ helped to identify the iodide ion as the active reactant of the rate-determining step in both media. Equilibria (21)-(23) lower its concentration in the vicinity. The reaction is catalyzed by the protonation of triiodide to produce $\mathrm{HI}_{3}$, which eliminates the rate-slowing $\mathrm{I}_{3}{ }^{-}$and supports the interaction between iodide and dicyanobis(pipyridine)iron(III). Up to $0.1 \mathrm{M} \mathrm{H}^{+}$, a linear fit was observed in $10 \%$ binary solvent media, as previously discussed. As a result of the higher volume fraction of 1,4-dioxane to water in $20 \%$ binary solvent media, the media have strong and excess hydrogen bonding compared to $10 \%$ media. As a result, equilibrium (23) is expected to be established at a concentration of $1 \mathrm{mM}$, and an excessive addition of protons does not reduce the concentration of rate resisting $\mathrm{I}_{3}{ }^{-}$, but it does delay the effective collisions between the monopositive oxidant, dicyanobis(bipyridine)iron(III), and the iodide ion. We found identical values of the observed zero-order rate constant for iodide oxidation in $20 \%$ binary solvent media without and with 0.01-0.1 $\mathrm{M} \mathrm{H}^{+}$. 


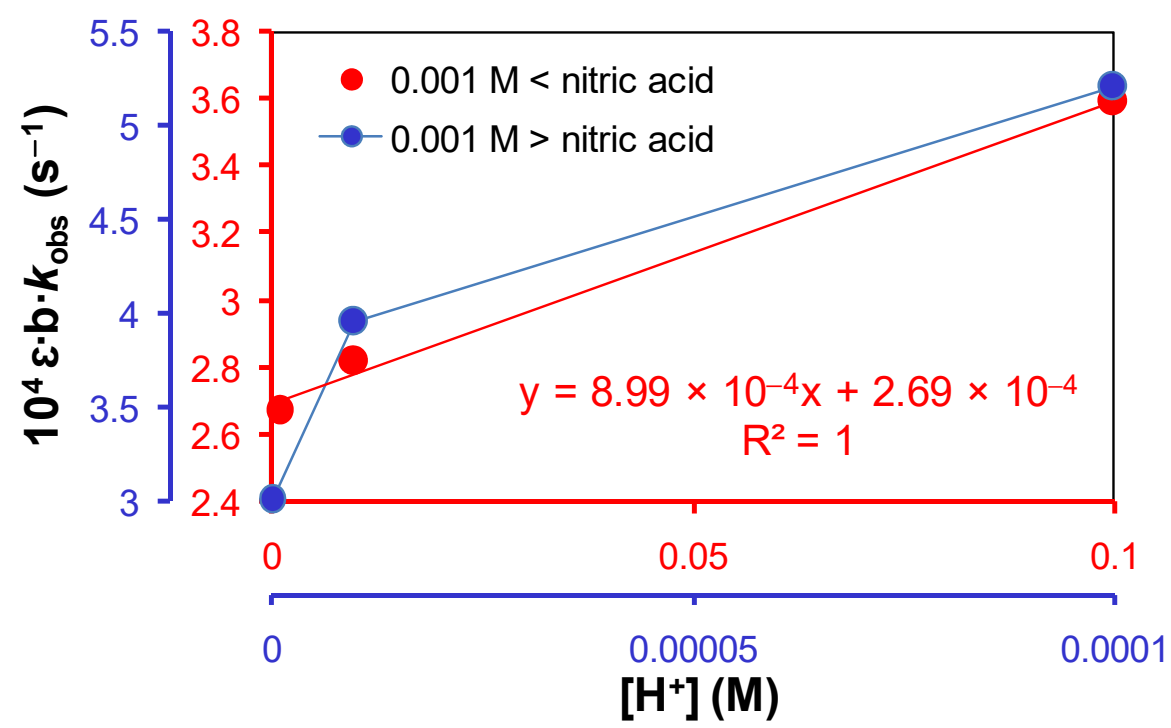

(a)

$\log \left(\left[\mathrm{H}^{+}\right] / \mathrm{M}\right)$

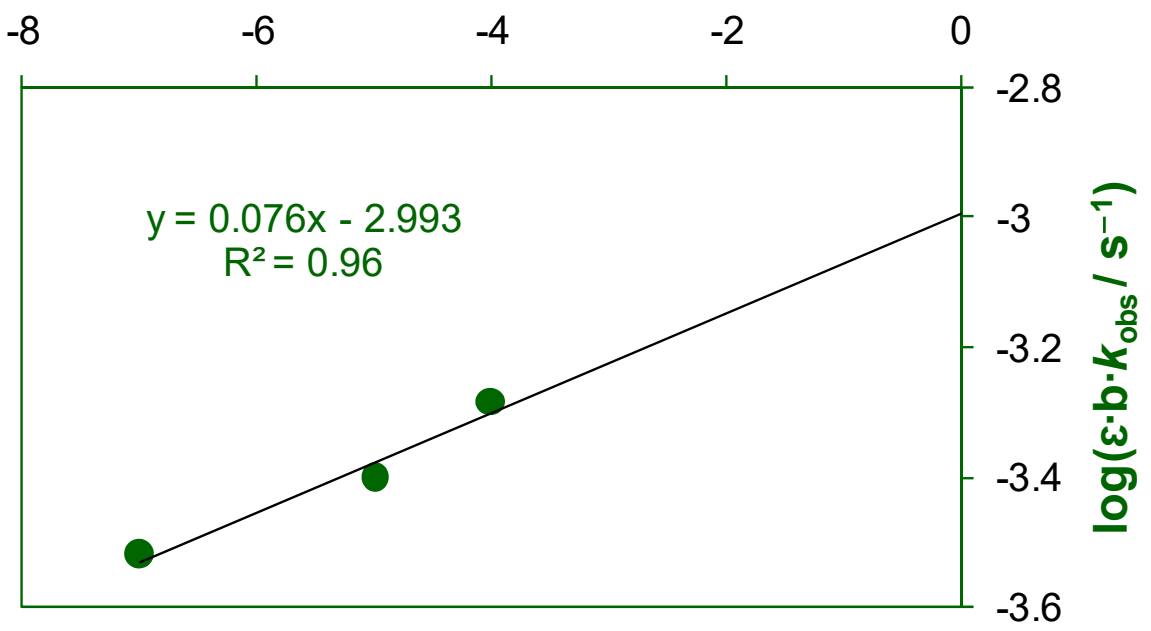

(b)

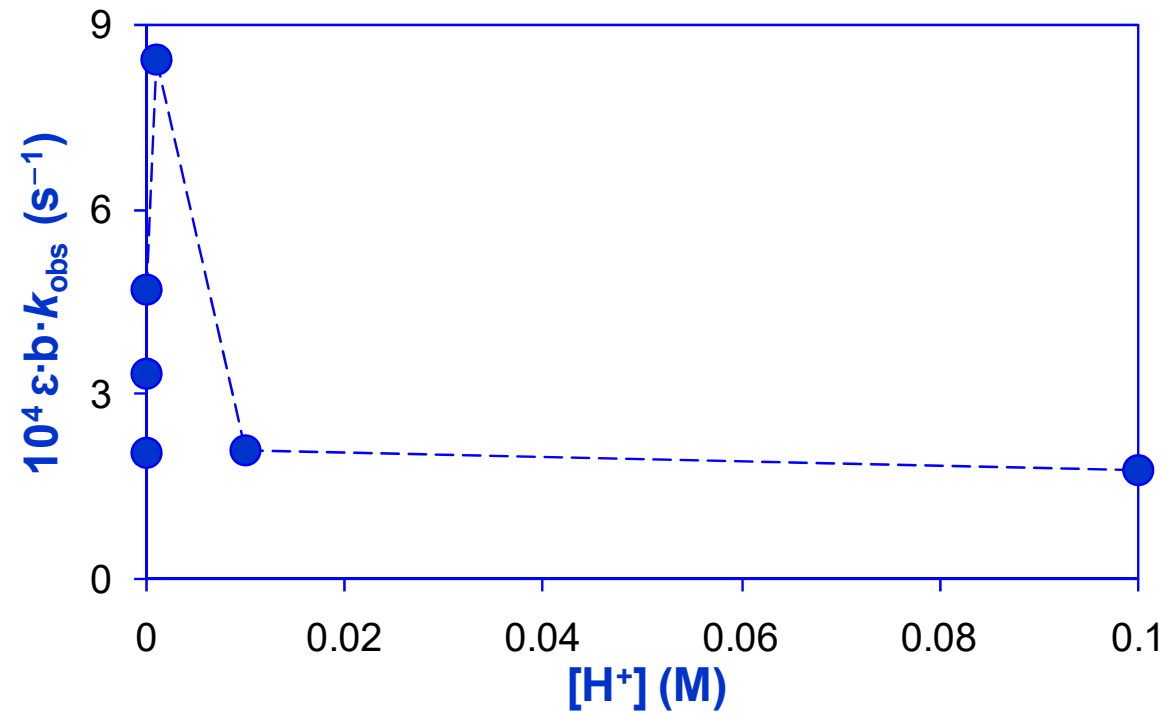

(c)

Figure 8. Cont. 


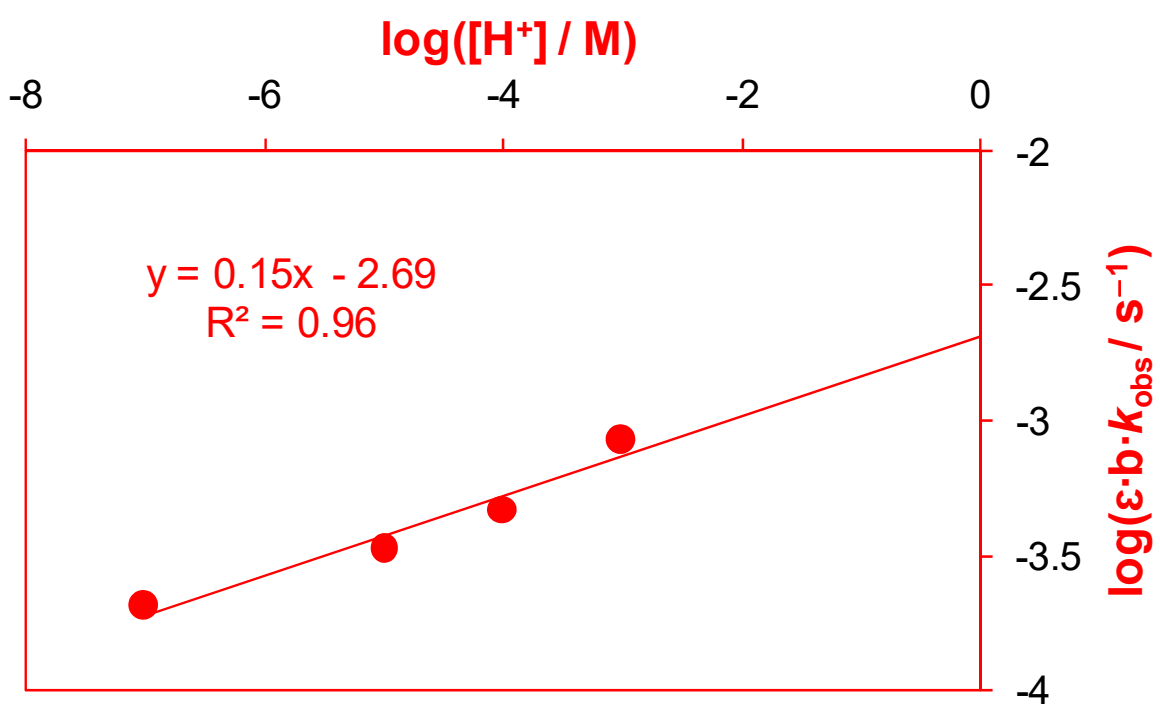

(d)

Figure 8. (a) Proton catalyzing effect on the rate constant in $10 \% v / v$ dioxane-water at $288 \pm 0.5 \mathrm{~K}$. (b) Proton catalyzing effect on the rate constant (log-log plot) in 10\% v/v dioxane-water at $288 \pm 0.5 \mathrm{~K}$. (c) Proton catalyzing effect on the rate constant in $20 \% v / v$ dioxane-water at $285 \pm 0.5 \mathrm{~K}$. (d) Proton catalyzing effect on the rate constant (log-log plot) in $20 \% v / v$ dioxane-water at $285 \pm 0.5 \mathrm{~K}$.

For further rectification of the results, the effect of ionic strength on the observed zero-order rate constant was studied in both $10-20 \%$ binary solvent media. We proposed iodide as the reactive species that controls the rate-determining step and leads the reaction mechanism. As a result, according to the formulation of the transition state theory (Equation (40)), our results should produce a linear fit with a negative slope. For greater ionic strength values, Equation (40) is employed, where A is the Debye-Hückel constant. Its mathematical value is determined by the solvent/media's composition and dielectric constant as well as temperature. The dielectric constant is lowered in $10-20 \%$ reaction media, and a robust hydrogen bonding network is generated. As a result, the ionic strength we utilized for the uncatalyzed reaction becomes strong in both binary solvent media, making Equation (27) ineffective. Equation (40) is used when the ionic strength is high.

$$
\log \left(\varepsilon \cdot \mathrm{b} \cdot k_{\mathrm{obs}}\right)=\log \varepsilon \cdot \mathrm{b} \cdot\left(k_{\mathrm{obs}}\right)_{0}+2 \mathrm{Az} \mathrm{z}_{\mathrm{A}} \mathrm{z}_{\mathrm{B}} \frac{\sqrt{\mu}}{1+\sqrt{\mu}}
$$

In both reaction media, the plot of $\log _{10}\left(\epsilon \cdot \mathrm{b} \cdot k_{\mathrm{obs}}\right)$ versus $\sqrt{\mu} / 1+\sqrt{\mu}$ produces a straight line with a negative slope value, confirming our hypothesis (Figure $9 a, b$ ). 


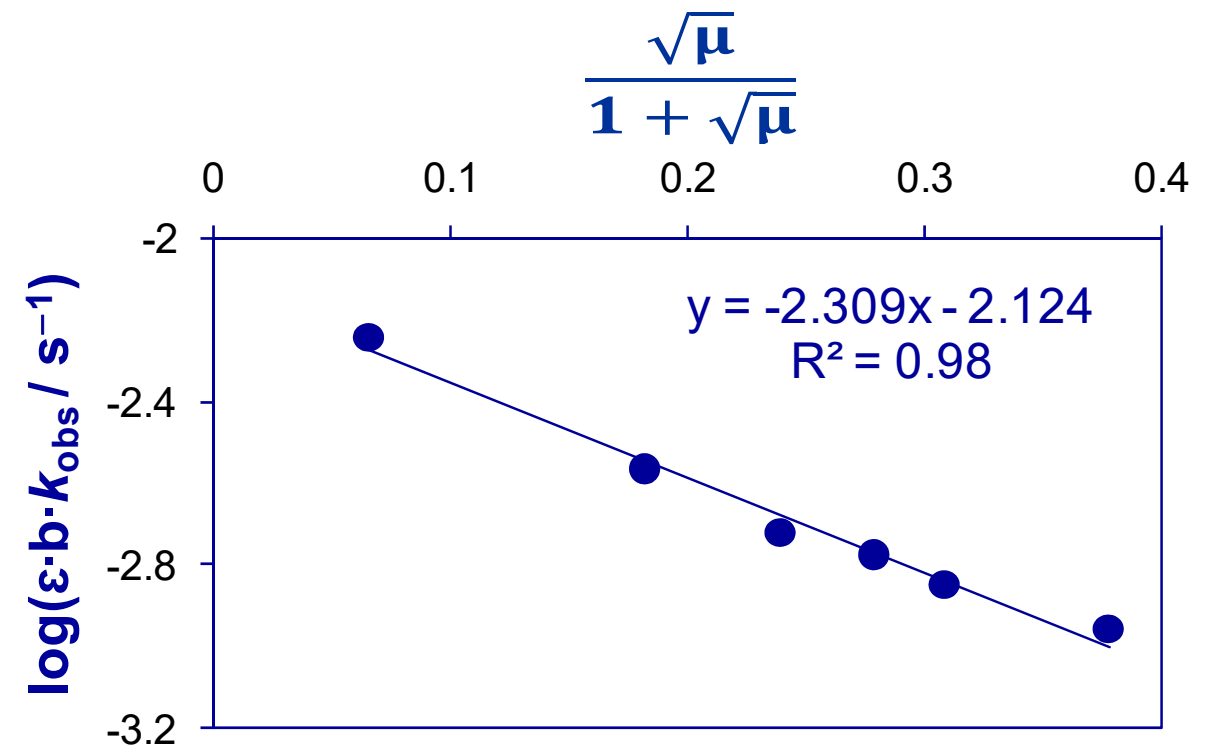

(a)

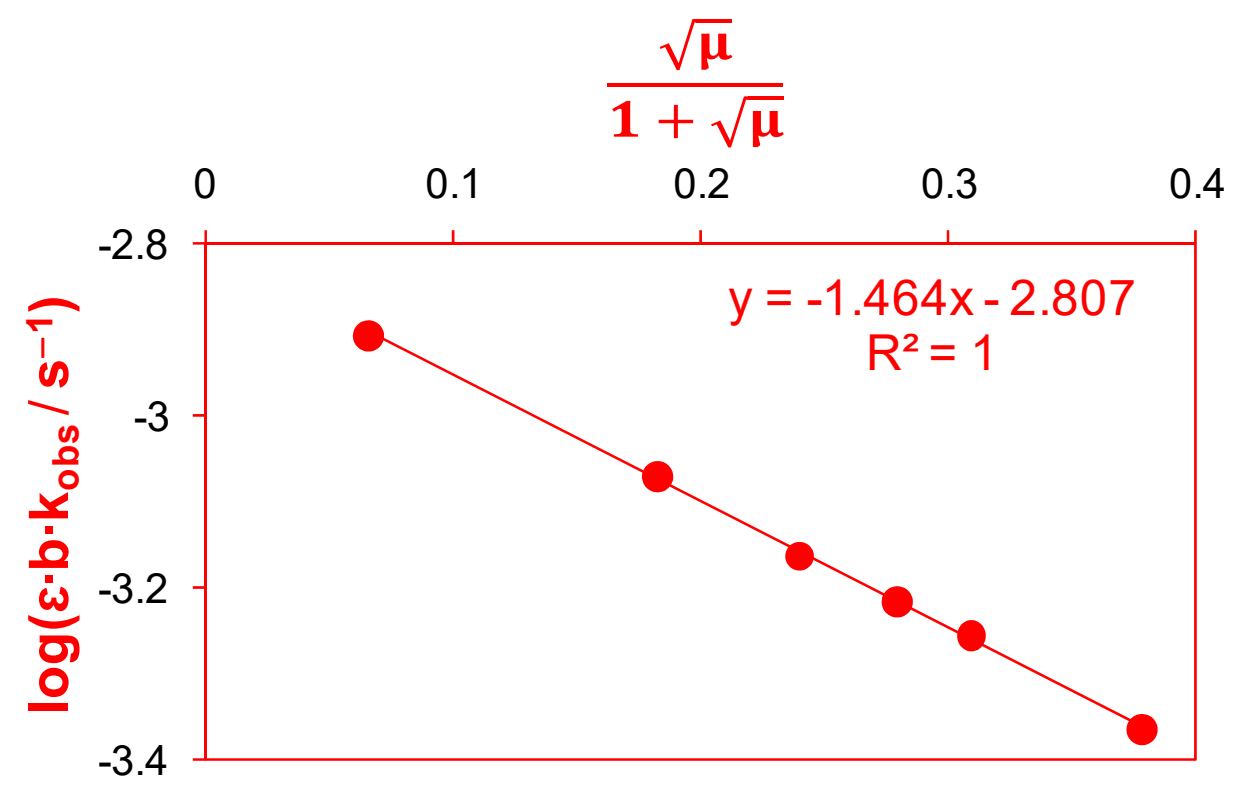

(b)

Figure 9. (a) Plot of the effect of ionic strength on the observed rate constant in $10 \% v / v$ dioxanewater at $288 \pm 0.5 \mathrm{~K}$. (b) Plot of the effect of ionic strength on the observed rate constant in $20 \% v / v$ dioxane-water at $289 \pm 0.5 \mathrm{~K}$.

\section{Materials and Methods}

\subsection{Materials and Instrumentation}

Without further purification, potassium iodide (Sigma-Aldrich), potassium nitrate (Sigma-Aldrich), 1,4-dioxane (Sigma-Aldrich), and nitric acid (Merck) were used as supplied. The transition metal complex (dicyanobis(bipyridine)iron(III) nitrate) was synthesized, purified, and characterized, as previously reported [30]. Deionized water was used to maintain the aqueous proportion of the media. As a result of the dioxane-water, the quartz cuvettes were used to collect absorbance versus wavelength/time data using the Vernier Go Direct ${ }^{\mathrm{TM}}$ SpectroVis plus spectrophotometer + fluorometer. The visible range is covered by the spectrophotometer. The equipment was linked to a laptop via USB, and data were recorded in spectrum/kinetic mode using the Logger Pro 3.15 program. To make $3 \mathrm{~mL}$ in a quartz cuvette with a $1 \mathrm{~cm}$ path length, disposable syringes were used to combine $1.5 \mathrm{~mL}$ of each reactant, such as the oxidant and the reductant. 


\subsection{Kinetic Measurements}

The kinetics of the reaction was followed by measuring the increase in absorbance with time at $520.2 \mathrm{~nm}$ (water), $533.9 \mathrm{~nm}(10 \% v / v$ 1,4-dioxane-water), and $535.5 \mathrm{~nm}(20 \%$ $v / v$ 1,4-dioxane-water) when dicyanobis(bipyridine)iron(II) was formed. It is worth noting that the oxidant; dicyanobis(bipyridine)iron(III) absorbs at this wavelength as well. As a result of its poor molar absorptivity in comparison to its reduced form, this absorption is relatively low.Consequently, before the start of the reaction, we observed absorbance at zero time. The representative time course graph of the redox reaction is shown in Figure $2 \mathrm{a}, \mathrm{b}$. In all reaction media, the reaction was analyzed at room temperature. To assess the rate dependence upon the reactants in all reaction media at $0.06 \mathrm{M}$ ionic strength $(\mu)$, the oxidant concentration was kept constant at $0.08 \mathrm{mM}$ and the iodide (reductant) concentration was varied between 0.08 and $4 \mathrm{mM}$ at 1:1, 1:2.5, 1:5, 1:7.5, 1:10, 1:20, 1:30, 1:40, and 1:50 times. During the analysis of the effect of various parameters such as protons, ionic strength, and temperature, the concentration ratio between oxidizing and reducing agents was set at $\left[\mathrm{Fe}^{\mathrm{III}}(\text { bpy })_{2}(\mathrm{CN})_{2}\right]^{+}<<<\mathrm{I}^{-}$such that 1:10, respectively. Nitric acid was used to introduce protons in concentrations of $0 \mathrm{M}, 0.01 \mathrm{mM}, 0.1 \mathrm{mM}, 1 \mathrm{mM}, 10 \mathrm{mM}$, and $100 \mathrm{mM}$. Ionic strength was varied at $0.005,0.05,0.1,0.15,0.2$, and 0.37 . However, the temperature ranged from 10 to $40{ }^{\circ} \mathrm{C}$. Each experiment was repeated three times to ensure that the kinetics was followed precisely. The average of the three readings was used to calculate the rate constant. In all reaction media, the reactants and products were identified by their visible spectra (Figure 10a,c).

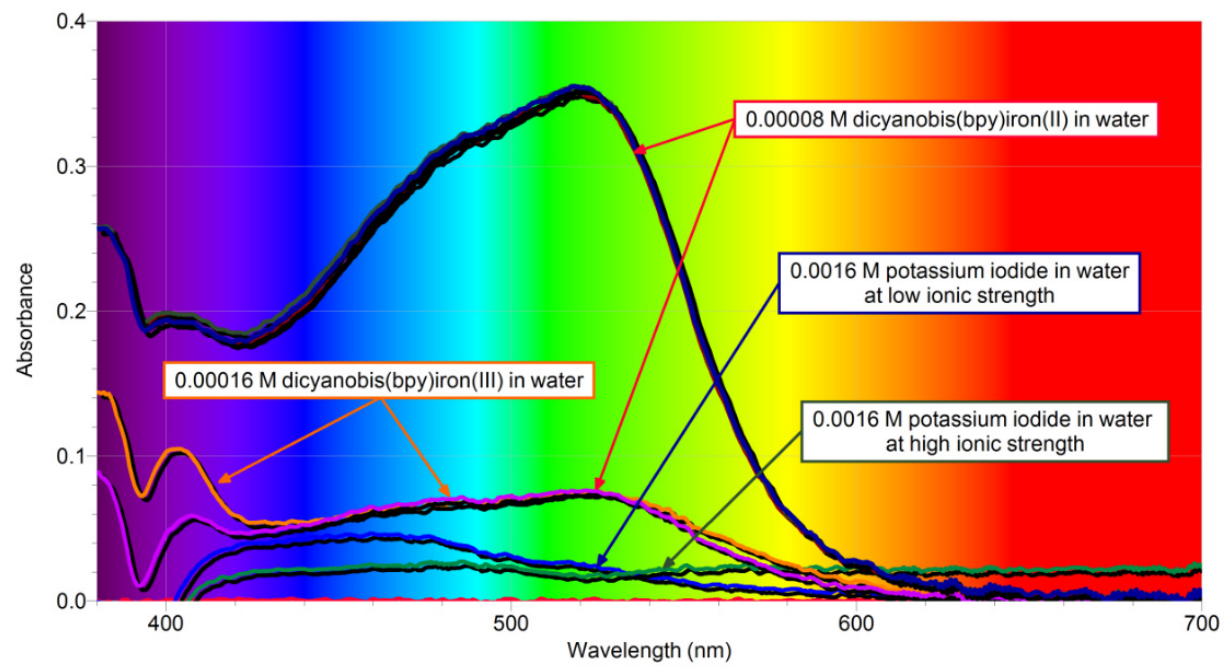

(a)

Figure 10. Cont. 


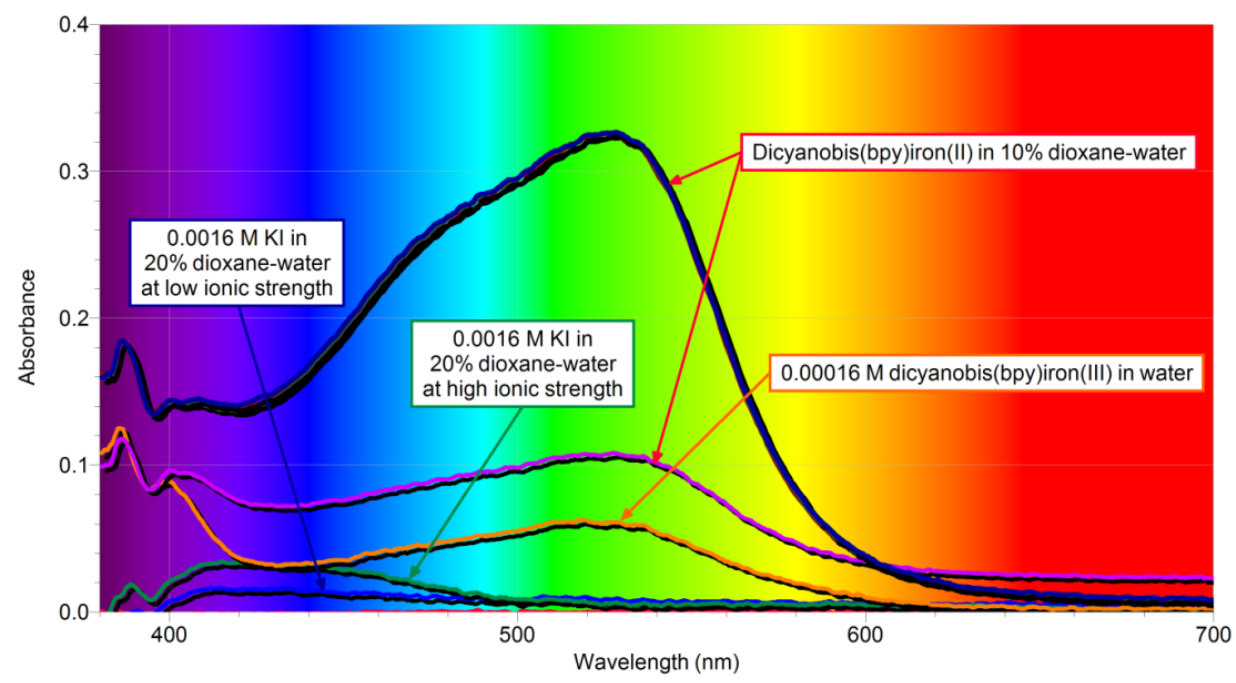

(b)

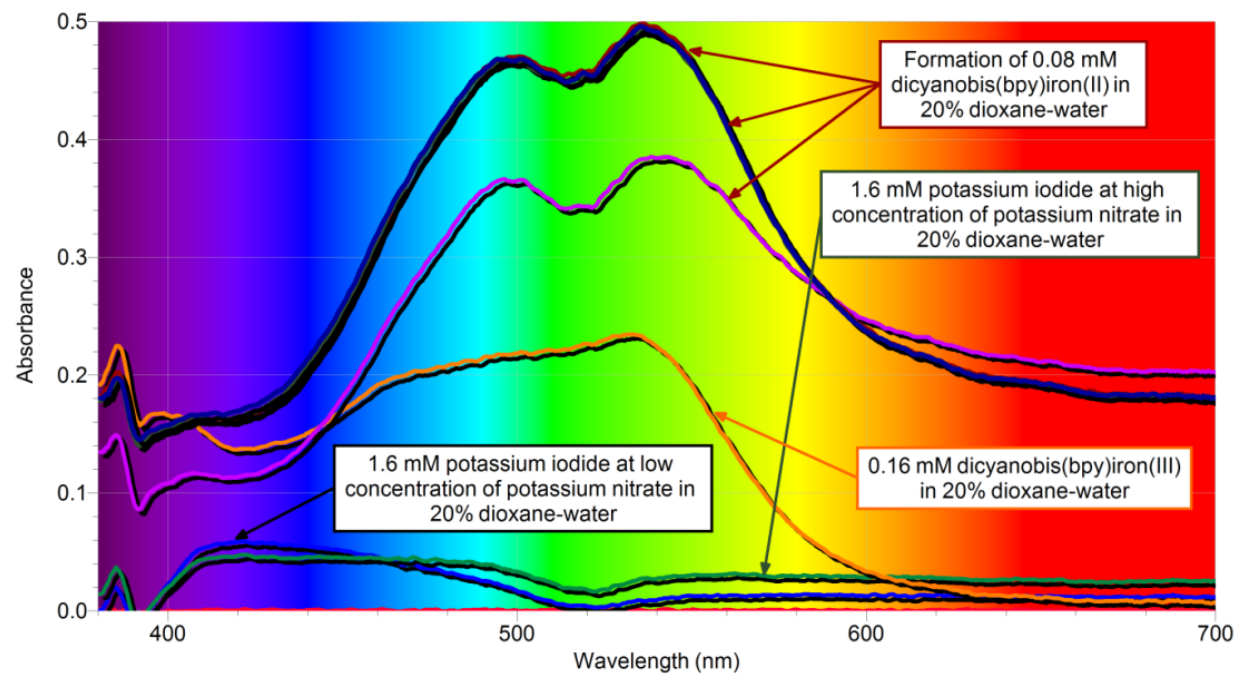

(c)

Figure 10. (a) Visible absorption spectra of reactants and product in water. (b) Visible absorption spectra of reactants and product in 10\% $v / v$ 1,4-dioxane-water. (c) Visible absorption spectra of reactants and product in $20 \% v / v$ 1,4-dioxane-water.

\section{Conclusions}

The oxidation of iodide by dicyanobis(bipyridine)iron(III) proceeds through a moderate rate and with a comparatively low value of the rate constant in water. The rate of reaction depends upon the fractional (0.5) power of the concentration term of the iodide ion only. The concentration of the oxidant i.e., dicyanobis(bipyridine)iron(III), has no effect on the rate of reaction. The reaction is led by the formation of iodine and its subsequent conversion to triiodide ion, which reduces dicyanobis(bipyridine)iron(III) by donating electron. As a result of the protonation of triiodide, the rate slows down. However, this reaction is catalyzed by adding a small volume of 1,4-dioxane to water, and the rate achieves its maximal value. If the third power of the concentration terms of the reactants is involved in the rate law, the reaction is considered to be at its full rate. In the oxidation of iodide by dicyanobis(bipyridine)iron(III), the iodide ion is the only species whose concentration determines the rate of reaction. The addition of a small volume fraction of 1,4-dioxane such as $20 \%$ to water accelerates the rate of reaction to the third power of iodide ion with a remarkable high value of the third-order rate constant. The 10\% volume fraction of 1,4-dioxane to water doubles the rate of reaction by first order in iodide ion that was 0.5 order in water. The $20 \%$ volume fraction of 1,4-dioxane to water has the highest catalytic 
efficiency in the oxidation of iodide by dicyanobis(bipyridine)iron(III). In the binary solvent media, the iodide ion leads the rate of reaction by participating directly in the rate-limiting step without converting to any other intermediate species. The formation of triiodide ion and its protonation are the rate decelerating and accelerating factors in the binary solvent media, respectively. Concisely, this study identified the environmentally benign and cost-effective procedure to improve the efficiency of the dye-sensitized solar cells.

Author Contributions: Conceptualization, R.K. and M.S.K.; methodology, R.K. and S.S.; software, R.K. and Z.I.; validation, R.K., R.U., A.K., M.Z. and H.N.; formal analysis, R.K., M.S.K., R.U., A.K., Z.I., S.S. and H.N.; investigation, R.K. and M.S.K.; resources, R.K., M.Z., S.M.E.-B. and G.E.-S.B.; data curation, R.K. and M.S.K.; writing—original draft preparation, R.K.; writing—review and editing, S.M.E.-B., M.Z. and G.E.-S.B.; visualization, R.K.; supervision, R.K.; project administration, S.M.E.-B.; funding acquisition, S.M.E.-B. All authors have read and agreed to the published version of the manuscript.

Funding: The APC was funded by Taif University Researchers Supporting Project number TURSP2020/135, Taif University, Taif, Saudi Arabia.

Acknowledgments: The authors gratefully acknowledge financial support from Taif University Researchers Supporting Project number TURSP-2020/135, Taif University, Taif, Saudi Arabia.

Conflicts of Interest: The authors declare no conflict of interest. The funders had no role in the design of the study; in the collection, analyses, or interpretation of data; in the writing of the manuscript, or in the decision to publish the results.

\section{References}

1. Kokkonen, M.; Talebi, P.; Zhou, J.; Asgari, S.; Soomro, S.A.; Elsehrawy, F.; Halme, J.; Ahmad, S.; Hagfeldt, A.; Hashmi, S.G. Advanced research trends in dye-sensitized solar cells. J. Mater. Chem. A 2021, 9, 10527-10545. [CrossRef]

2. Venkatraman, V.; Raju, R.; Oikonomopoulos, S.P.; Alsberg, B.K. The dye-sensitized solar cell database. J. Cheminformatics 2018, 10, 1-9. [CrossRef]

3. Sharma, K.; Sharma, V.; Sharma, S.S. Dye-Sensitized Solar Cells: Fundamentals and Current Status. Nanoscale Res. Lett. 2018, 13, 1-46. [CrossRef]

4. Karthick, S.; Hemalatha, K.; Balasingam, S.K.; Clinton, F.M.; Akshaya, S.; Kim, H. Dye-Sensitized Solar Cells: History, Components, Configuration, and Working Principle. In Interfacial Engineering in Functional Materials for Dye-Sensitized Solar Cells; John Wiley \& Sons: Hoboken, NJ, USA, 2019; pp. 1-16.

5. Ung, M.C.; Sipaut, C.S.; Dayou, J.; Liow, K.S.; Kulip, J.; Mansa, R.F. Fruit based Dye Sensitized Solar Cells. IOP Conf. Ser. Mater. Sci. Eng. 2017, 217, 12003. [CrossRef]

6. Cavallo, C.; Di Pascasio, F.; Latini, A.; Bonomo, M.; Dini, D. Nanostructured Semiconductor Materials for Dye-Sensitized Solar Cells. J. Nanomater. 2017, 2017, 5323164. [CrossRef]

7. Trihutomo, P.; Soeparman, S.; Widhiyanuriyawan, D.; Yuliati, L. Performance Improvement of Dye-Sensitized Solar Cell- (DSSC-) Based Natural Dyes by Clathrin Protein. Int. J. Photoenergy 2019, 2019, 1-9. [CrossRef]

8. Huaulmé, Q.; Mwalukuku, V.M.; Joly, D.; Liotier, J.; Kervella, Y.; Maldivi, P.; Narbey, S.; Oswald, F.; Riquelme, A.J.; Anta, J.A.; et al. Photochromic dye-sensitized solar cells with light-driven adjustable optical transmission and power conversion efficiency. Nat. Energy 2020, 5, 468-477. [CrossRef]

9. Rondan-Gomez, V.; De Los Santos, I.M.; Seuret-Jiménez, D.; Ayala-Mató, F.; Zamudio-Lara, A.; Robles-Bonilla, T.; Courel, M. Recentadvances in dye-sensitizedsolarcells. Appl. Phys. A 2019, 125, 836. [CrossRef]

10. Bignozzi, C.A.; Argazzi, R.; Boaretto, R.; Busatto, E.; Carli, S.; Ronconi, F.; Caramori, S. The role of transition metal complexes in dye sensitized solar devices. Coord. Chem. Rev. 2013, 257, 1472-1492. [CrossRef]

11. Grätzel, M. Dye-sensitized solar cells. J. Photochem. Photobiol. C Photochem. Rev. 2003, 4, 145-153. [CrossRef]

12. Hagfeldt, A.; Boschloo, G.; Sun, L.; Kloo, L.; Pettersson, H. Dye-Sensitized Solar Cells. Chem. Rev. 2010, 110, 6595-6663. [CrossRef]

13. Grätzel, M. Perspectives for dye-sensitized nanocrystalline solar cells. Prog. Photovolt. Res. Appl. 2000, 8, 171-185. [CrossRef]

14. Hagfeldt, A.; Grätzel, M. Molecular Photovoltaics. Acc. Chem. Res. 2000, 33, 269-277. [CrossRef] [PubMed]

15. Nazeeruddin, K.; Pechy, P.; Gratzel, $\mathrm{M}$. Efficient panchromatic sensitization of nanocrystalline $\mathrm{TiO}_{2}$ films by a black dye based on a trithiocyanato-ruthenium complex. Chem. Commun. 1997, 18, 1705-1706. [CrossRef]

16. Saadmim, F.; Forhad, T.; Sikder, A.; Ghann, W.; Ali, M.M.; Sitther, V.; Ahammad, A.J.S.; Subhan, A.; Uddin, J. Enhancing the Performance of Dye Sensitized Solar Cells Using Silver Nanoparticles Modified Photoanode. Molecules 2020, 25, 4021. [CrossRef]

17. Tang, B.; Yu, H.; Peng, H.; Wang, Z.; Li, S.; Ma, T.; Huang, W. Graphene based photoanode for DSSCs with high performances. RSC Adv. 2018, 8, 29220-29227. [CrossRef]

18. Song, W.; Gong, Y.; Tian, J.; Cao, G.; Zhao, H.; Sun, C. Novel Photoanode for Dye-Sensitized Solar Cells with Enhanced Light-Harvesting and Electron-Collection Efficiency. ACS Appl. Mater. Interfaces 2016, 8, 13418-13425. [CrossRef] 
19. Yan, L.-T.; Wu, F.-L.; Peng, L.; Zhang, L.-J.; Li, P.-J.; Dou, S.-Y.; Li, T.-X. Photoanode of Dye-Sensitized Solar Cells Based on a $\mathrm{ZnO} / \mathrm{TiO}_{2}$ Composite Film. Int. J. Photoenergy 2012, 2012, 1-4. [CrossRef]

20. Bhattacharjee, R.; Hung, I.-M. A $\mathrm{SnO}_{2}$ and ZnO Nanocomposite Photoanodes in Dye-Sensitized Solar Cells. ECS Solid State Lett. 2013, 2, Q101-Q104. [CrossRef]

21. Zhang, S.; Jin, J.; Li, D.; Fu, Z.; Gao, S.; Cheng, S.; Yu, X.; Xiong, Y. Increased power conversion efficiency of dye-sensitized solar cells with counter electrodes based on carbon materials. RSC Adv. 2019, 9, 22092-22100. [CrossRef]

22. Wang, H.; Wei, W.; Hu, Y.H. NiO as an Efficient Counter Electrode Catalyst for Dye-Sensitized Solar Cells. Top. Catal. 2013, 57, 607-611. [CrossRef]

23. Meyer, E.; Mbese, J.; Mutukwa, D.; Zingwe, N. Structural, Morphological and Electrochemical Characterization of Hydrothermally Fabricated PdNiCo and PdNiCo-rGO Alloys for Use as Counter Electrode Catalysts in DSSC. Mater. Basel 2019, 12, 3256. [CrossRef]

24. Xu, T.; Kong, D.; Tang, H.; Qin, X.; Li, X.; Gurung, A.; Kou, K.; Chen, L.; Qiao, Q.; Huang, W. Transparent MoS 2 /PEDOT Composite Counter Electrodes for Bifacial Dye-Sensitized Solar Cells. ACS Omega 2020, 5, 8687-8696. [CrossRef] [PubMed]

25. Li, Y.-Y.; Li, C.-T.; Yeh, M.-H.; Huang, K.-C.; Chen, P.-W.; Vittal, R.; Ho, K.-C. Graphite with Different Structures as Catalysts for Counter Electrodes in Dye-sensitized Solar Cells. Electrochim. Acta 2015, 179, 211-219. [CrossRef]

26. Mathew, A.; Rao, G.M.; Munichandraiah, N. Dye sensitized solar cell based on platinum decorated multiwall carbon nanotubes as catalytic layer on the counter electrode. Mater. Res. Bull. 2011, 46, 2045-2049. [CrossRef]

27. Peng, J.-D.; Wu, Y.-T.; Yeh, M.-H.; Kuo, F.-Y.; Vittal, R.; Ho, K.-C. Transparent Cobalt Selenide/Graphene Counter Electrode for Efficient Dye-Sensitized Solar Cells with $\mathrm{Co}^{2+/ 3+}$-Based Redox Couple. ACS Appl. Mater. Interfaces 2020, 12, 44597-44607. [CrossRef]

28. Khattak, R.; Khan, M.S.; Ullah, R.; Ali, M.; Rahman, W.; Hakeem, F.; Ayaz, K.; Bibi, Z. Effect of the ionic strength on the redox reaction of dicyanobis(bipyridine)iron(III)-iodide in binary and ternary solvent systems. Int. J. Chem. Kinet. 2021, 53, 16-26. [CrossRef]

29. Boschloo, G.; Hagfeldt, A. Characteristics of the Iodide/Triiodide Redox Mediator in Dye-Sensitized Solar Cells. Acc. Chem. Res. 2009, 42, 1819-1826. [CrossRef] [PubMed]

30. Lin, Y.C.; Chou, J.C.; Lai, C.H.; Kuo, P.Y.; Nien, Y.H.; Chang, J.X.; Hu, G.M.; Yong, Z.R. Dye-Sensitized Solar Cell Using $\mathrm{TiO}_{2}$ /AgNWs Film: Application under Low Illumination. In Proceedings of the 2020 IEEE Eurasia Conference on IOT, Communication and Engineering (ECICE), Yunlin, Taiwan, 23-25 October 2020; pp. 353-354.

31. Boschloo, G. Improving the Performance of Dye-Sensitized Solar Cells. Front. Chem. 2019, 7, 77. [CrossRef] [PubMed]

32. Kalaignan, G.P.; Kang, M.-S.; Kang, Y.S. Effects of compositions on properties of PEO-KI-I 2 salts polymer electrolytes for DSSC. Solid State Ion. 2006, 177, 1091-1097. [CrossRef]

33. Rowley, J.G.; Farnum, B.H.; Ardo, S.; Meyer, G.J. Iodide Chemistry in Dye-Sensitized Solar Cells: Making and Breaking I-I Bonds for Solar Energy Conversion. J. Phys. Chem. Lett. 2010, 1, 3132-3140. [CrossRef]

34. Wang, T.-H.; Huang, T.-W.; Liao, C.-S.; Tsai, Y.-C.; Chang, Y.-W. A photoluminescent layer for improving the performance of dye-sensitized solar cells. Chem. Commun. 2015, 51, 7253-7256. [CrossRef]

35. Pradhan, S.C.; Hagfeldt, A.; Soman, S. Resurgence of DSCs with copper electrolyte: A detailed investigation of interfacial charge dynamics with cobalt and iodine based electrolytes. J. Mater. Chem. A 2018, 6, 22204-22214. [CrossRef]

36. Khattak, R.; Khan, M.S.; Summer, S.; Ullah, R.; Afridi, H.; Rehman, Z.; Masood, S.; Noreen, H.; Qazi, R.A.; Begum, B. Kinetics of the oxidation of iodide by dicyanobis(phenanthroline)iron(III) in a binary solvent system. Int. J. Chem. Kinet. 2021, 53, $230-241$. [CrossRef]

37. Ammar, A.M.; Mohamed, H.; Yousef, M.M.K.; Abdel-Hafez, G.M.; Hassanien, A.S.; Khalil, A.S.G. Dye-Sensitized Solar Cells (DSSCs) Based on Extracted Natural Dyes. J. Nanomater. 2019, 2019, 1-10. [CrossRef]

38. Mathew, S.; Yella, A.; Gao, P.; Humphry-Baker, R.; Curchod, B.F.E.; Ashari-Astani, N.; Tavernelli, I.; Rothlisberger, U.; Nazeeruddin, K.; Graetzel, M. Dye-Sensitized solar cells with $13 \%$ efficiency achieved through the molecular engineering of porphyrin sensitizers. Nat. Chem. 2014, 6, 242-247. [CrossRef]

39. Kakiage, K.; Aoyama, Y.; Yano, T.; Oya, K.; Fujisawa, J.-I.; Hanaya, M. Highly-Efficient dye-sensitized solar cells with collaborative sensitization by silyl-anchor and carboxy-anchor dyes. Chem. Commun. 2015, 51, 15894-15897. [CrossRef]

40. Mukherjee, S.; Bowman, D.N.; Jakubikova, E. Cyclometalated Fe(II) Complexes as Sensitizers in Dye-Sensitized Solar Cells. Inorg. Chem. 2015, 54, 560-569. [CrossRef]

41. Huang, Y.; Chen, W.-C.; Zhang, X.-X.; Ghadari, R.; Fang, X.-Q.; Yu, T.; Kong, F.-T. Ruthenium complexes as sensitizers with phenyl-based bipyridine anchoring ligands for efficient dye-sensitized solar cells. J. Mater. Chem. C 2018, 6, 9445-9452. [CrossRef]

42. Gao, S.; Fan, R.Q.; Wang, X.M.; Qiang, L.S.; Wei, L.G.; Wang, P.; Yang, Y.L.; Wang, Y.L. Advanced CdII complexes as high efficiency co-sensitizers for enhanced dye-sensitized solar cell performance. Dalton Trans. 2015, 44, 18187-18195. [CrossRef]

43. Gondane, V.; Bhargava, P. Acetylacetone: A promising electrolyte solvent for dye sensitized solar cells. RSC Adv. 2016, 6, 37167-37172. [CrossRef]

44. Fukui, A.; Komiya, R.; Yamanaka, R.; Islam, A.; Han, L. Effect of a redox electrolyte in mixed solvents on the photovoltaic performance of a dye-sensitized solar cell. Sol. Energy Mater. Sol. Cells 2006, 90, 649-658. [CrossRef]

45. Gu, P.; Yang, D.; Zhu, X.; Sun, H.; Wangyang, P.; Li, J.; Tian, H. Influence of electrolyte proportion on the performance of dye-sensitized solar cells. AIP Adv. 2017, 7, 105219. [CrossRef] 
46. Abu Talip, R.; Yahya, W.; Bustam, M. Ionic Liquids Roles and Perspectives in Electrolyte for Dye-Sensitized Solar Cells. Sustainability 2020, 12, 7598. [CrossRef]

47. Shi, L.-Y.; Chen, T.-L.; Chen, C.-H.; Cho, K.-C. Synthesis and Characterization of a Gel-Type Electrolyte with Ionic Liquid Added for Dye-Sensitized Solar Cells. Int. J. Photoenergy 2013, 2013, 1-7. [CrossRef]

48. Wu, J.; Lan, Z.; Lin, J.; Huang, M.; Li, P. Effect of solvents in liquid electrolyte on the photovoltaic performance of dye-sensitized solar cells. J. Power Sources 2007, 173, 585-591. [CrossRef]

49. Boldrini, C.L.; Manfredi, N.; Perna, F.M.; Capriati, V.; Abbotto, A. Eco-Friendly Sugar-Based Natural Deep Eutectic Solvents as Effective Electrolyte Solutions for Dye-Sensitized Solar Cells. ChemElectroChem 2020, 7, 1707-1712. [CrossRef]

50. Subramania, A.; Vijayakumar, E.; Sivasankar, N.; Priya, A.R.S.; Kim, K.-J. Effect of different compositions of ethylene carbonate and propylene carbonate containing iodide/triiodide redox electrolyte on the photovoltaic performance of DSSC. Ionics 2013, 19, 1649-1653. [CrossRef]

51. Srivishnu, K.S.; Prasanthkumar, S.; Giribabu, L. Cu(ii/i) redox couples: Potential alternatives to traditional electrolytes for dye-sensitized solar cells. Mater. Adv. 2021, 2, 1229-1247. [CrossRef]

52. Summer, S.; Shamim, A.; Khattak, R.; Qamar, N.; Naqvi, I.I. An Insight into the Kinetics and Mechanism of Oxidation of Tris (4,4'-dimethyl-2,2'-bipyridine)iron(II) by Bromate. Russ. J. Phys. Chem. A 2020, 94, 544-550. [CrossRef]

53. Summer, S.; Naqvi, I.I.; Khattak, R.; Gulzar, S.; Reyaz, F. Kinetics and Mechanism of $\left[\mathrm{Fe}(\text { bipy })_{3}\right]^{2+}$ and $\left[\mathrm{BrO}_{3}{ }^{-}\right] \mathrm{System}$ in $\mathrm{Aqueous}^{-}$ Acidic Medium. J. Chem. Soc. Pak. 2016, 38, 384-389.

54. Khattak, R.; Naqvi, I.I.; Farrukh, M.A. Kinetics and mechanism of the oxidation of a ferrous complex with an $\alpha, \alpha^{\prime}$-diimine chelate ligand by ceric sulfate in aqueous acidic medium by UV-Vis absorption spectroscopy. J. Iran. Chem. Soc. 2008, 5, 631-640. [CrossRef]

55. Khattak, R.; Khan, M.S.; Naqvi, I.I. Mechanism of the electron-exchange reactions between mixed ligand Fe(III) complexes and cyano complex of Fe(II). Bulg. Chem. Commun. 2018, 50, 38-44.

56. Khattak, R.; Naqvi, I.I.; Summer, S.; Sayed, M. Mechanism of the oxidation of 1-(ferrocenyl)-ethanone/ethanol by dicyanobis(phenanthroline)iron(III). Arab. J. Chem. 2019, 12, 4240-4250. [CrossRef]

57. Khattak, R.; Naqvi, I.I. Study of the effect of structure on the kinetics and mechanism of the redox reactions of Fe(III)/Fe(II) complexes. Bulg. Chem. Commun. 2019, 51, 129-134.

58. Khattak, R.; Nazir, M.; Summer, S.; Sayed, M.; Minhaz, A.; Naqvi, I.I. Thermodynamic aspect: Kinetics of the reduction of dicyanobis(phen)iron(III) by acetylferrocene and methylferrocenemethanol. Chem. Pap. 2018, 72, 883-893. [CrossRef]

59. Khattak, R. Comparative Kinetic Study for the Electron Transfer Reactions of Some Iron Complexes. Ph.D. Thesis, University of Karachi, Karachi, Pakistan, 2011.

60. Khattak, R.; Naqvi, I.I. Identification, preparation and characterization of some iron complexes. J. Res. Sci. 2008, 19, 17-35.

61. Khattak, R.; Sayed, M.; Khan, M.S.; Noreen, H. Introductory Chapter: Redox-An Overview. In Redox; Khattak, R., Ed.; IntechOpen: London, UK, 2020; pp. 1-10.

62. Khattak, R.; Naqvi, I.I. Addition product of iron(II) complex of aromatic diimine with sulphuric acid. J. Res. Sci. 2007, 18, 219-235.

63. Wang, X.; Stanbury, D.M. Copper Catalysis of the Oxidation of Iodide by $\left[\mathrm{Fe}^{\mathrm{III}}(\mathrm{bpy})_{2}(\mathrm{CN})_{2}\right]^{+}$in Acetonitrile. J. Phys. Chem. A 2004, 108, 7637-7638. [CrossRef]

64. Wang, X.; Stanbury, D.M. Direct oxidation of l-cysteine by $\left[\mathrm{Fe}^{\mathrm{III}}(\mathrm{bpy})_{2}(\mathrm{CN})_{2}\right]^{+}$and $\left[\mathrm{Fe}^{\mathrm{III}}(\mathrm{bpy})(\mathrm{CN})_{4}\right]^{-}$. Inorg. Chem. 2008, 47, 1224-1236. [CrossRef] [PubMed]

65. Wang, X.; Stanbury, D.M. Oxidation of Iodide by a Series of Fe(III) Complexes in Acetonitrile. Inorg. Chem. 2006, 45, 3415-3423. [CrossRef] [PubMed]

66. Bella, F.; Gerbaldi, C.; Barolo, C.; Grätzel, M. Aqueous dye-sensitized solar cells. Chem. Soc. Rev. 2015, 44, 3431-3473. [CrossRef]

67. Tsukaue, Y.; Takimoto, Y.; Nakao, G.; Yoshida, K. Effect of NOx on Oxidation of Triiodide Ions. J. Nucl. Sci. Technol. 1994, 31, 813-820. [CrossRef] 